\title{
Transfigurations of The Miraculous Mandarin: The Significance of Genre in the Genesis of Bartók's Pantomime ${ }^{1}$
}

\author{
László VIKÁRIUS \\ Bartók Archives, Institute for Musicology \\ Research Centre for the Humanities \\ Táncsics Mihály u. 7., H-1014 Budapest, Hungary \\ Email: vikarius.laszlo@btk.mta.hu
}

Received: September 2019; accepted: December 2019

\begin{abstract}
Based on a fresh study of all primary sources of Bartók's The Miraculous Mandarin (composition: 1918/19, orchestration: 1924) the article reconsiders the entire history of composition and repeated revisions of the work. The original choice of genre (expressive "pantomime" in contrast to "ballet") seems to have played a significant role in this troubled history, which shows the composer's efforts to transform sections of the original "gesture" music into a more symphonic style often making the music more succinct. Puzzlingly, the first full score of the complete work and a revised edition of the piano reduction published posthumously in 1955 by Universal Edition present an abridged form of the work, which cannot be fully authenticated and was finally restored to its more complete form in Peter Bartók's new edition of 2000. Looking for the possible origin of the more obscure cuts, discussions with choreographer Aurelio Milloss in 1936 and Gyula Harangozó in 1939/40, both of whom later directed and danced productions of the work under the baton of János Ferencsik with great success (in Milan in 1942 and in Budapest in 1945, resp.), should probably be taken into consideration as these might have resulted in the integration of cuts into the published full score. Apart from trying to understand the different stages of the work's long evolution, the article argues that it is essential to study the original version in the compositional sources since it reveals Bartók's first concept of the piece composed in his period of highest expressionism.
\end{abstract}

Keywords: Béla Bartók, The Miraculous Mandarin, genre, pantomime, ballet 
... now that men, tired fathers, raised for peace went out to the lands worldwide to hide in trenches to kill each other sadly, almost without anger in their peaceful hearts, going through sufferings that surpass Dante's fantasy about the anguishes of Hell; now that the whole world considers the war an enormous disaster - this feeling must insolubly be saved for the next generations. They should know what it is; they should learn from it, if at all they are able to.

Melchior Lengyel (1916)

The Miraculous Mandarin, both the work itself and its uneasy, disquieting hero, symbolizes constant struggles with seemingly insurmountable difficulties: of fulfilment defiantly challenging all possible obstacles. This work's fate was doomed, at least during the composer's lifetime, by its world première in Cologne, provoking scandal, demonstrations and the immediate ban of the production's staging. It would be inaccurate, however, to assume that this resulted from bad luck; that if the composition and orchestration could have been completed at the opportune moment (that is, significantly earlier, in fact as early as 1920) and the initial performance would have taken place at a fitting venue such as in liberal Berlin rather than in the conservative Cologne, that this work could have reached a status comparable to Stravinsky's Sacre du printemps of 1913 in twentieth-century Western music. ${ }^{2}$ The adversity Bartók's work faced is not independent of its unique artistic radicalism. The lengthy composition history and repeated revisions indicate the difficulty Bartók experienced whilst creating his uncompromisingly expressive narration of the daring subject matter.

1. This essay is primarily based on my Hungarian article published in Magyar Zene 51/4 (2013), 410444, which itself drew upon various previous papers and lectures held alternately in Hungarian, English or German, and which are enumerated there in detail. This article contains, however, some new insights especially based on a recent study of the dancer and choreographer Aurelio (Aurél) Milloss's marked-up copy, now at the Fondazione Cini, Venice, of the published four-hand piano reduction of The Miraculous Mandarin (see Source $\mathbf{P}$ in the Appendix). Work on the sources and evolution of The Miraculous Mandarin was generously supported by OTKA (Hungarian Scientific Research Fund) in the framework of the Bartók Complete Edition project preparatory to the Béla Bartók Complete Critical Edition, which was finally launched in 2016 and from which four volumes have since been published. A critical edition of The Miraculous Mandarin shall, however, probably remain unpublished until 2044 when the copyright, the longest amongst Bartók's works, is due to expire, 70 years after the death of the playwright Melchior (Menyhért) Lengyel (1880-1974). Note that source sigla in parentheses refer to the descriptions of sources in the Appendix to the present article.

2. "Had the work been first performed in Berlin as Bartók wanted, or in Paris, and had Universal Edition been more adept at publicity, The Miraculous Mandarin might have gained a following comparable to that of Le Sacre du printemps." This is how John Vinton lamented in his pioneering article, in which he discusses the revisions of the Mandarin. See John VINTON, “The Case of The Miraculous Mandarin," The Musical Quarterly 50/1 (January 1964), 17. Cf. László Somfai's opinion in Vera LAMPERT and László SOMFAI, "Béla Bartók," in The New Grove Modern Masters: Bartók, Stravinsky, Hindemith (London: Macmillan, 1984), 54: "If it had been performed at the time of its completion in piano score (1918-1919), it might have produced a sensation to rival that of The Rite of Spring ...." 
His approach and creative processes regarding The Miraculous Mandarin might be aptly expressed by his description of his then most recent composition, the Five Songs op. 16 on poems by Endre Ady of 1916: "My Ady-Songs are so savage that for the moment I would not dare step on stage with them in Vienna."3

\section{A Pantomime}

A study of the composition history of Bartók's The Miraculous Mandarin might comfortably begin with a brief chronicle of its première, which was the only performance the composer himself attended. Eugen (Jenö) Szenkár, Hungarian-born conductor of the Cologne Opera House at the time who had also conducted the initial performances of Bartók's two earlier stage works outside Hungary (the opera Duke Bluebeard's Castle and the ballet The Wooden Prince in Frankfurt am Main), recalled the première of The Miraculous Mandarin on 27 November 1926:

I conducted the first performance of Bartók's great The Miraculous Mandarin, which later became vastly significant internationally. Countless rehearsals were needed because the piece was extremely difficult and unusually complicated for the orchestras of the period. But how should I describe the scandal which it elicited from the public and the newspapers! The première was followed by a chorus of whistles and booing. The scandal was so ear-splitting that the safety curtain had to be pulled down. ... A few bravos were also to be heard of course, but they were drowned out by the uproar. Then came the next day and the reviews! What was written is beyond expression, especially in the papers of the [Deutsche] Zentrumpartei [German Centre Party] and the Catholic Volkszeitung [People's Newspaper]! My dear friend did not let himself be disturbed, he insisted on entering some small revisions to the clarinet part and so was only worried about how he could get into the Opera House as soon as possible to look for the part amongst the orchestral materials. This was just typical of Bartók. ${ }^{4}$

How accurate Szenkár's description of his friend's behaviour was can be gauged from Bartók's contemporaneous correspondence with his publisher, Uni-

3. Bartók to Klára Gombossy, 29 July 1916, first quoted in Denijs DILLE, "Bartók et Ady," in id., Béla Bartók: Regards sur le passé (Louvain-la-Neuve: Institut supérieur d'archéologie et d'histoire de l'art collège Érasme, 1990), 299. On this important correspondence, see László VIKÁRIUS, "Intimations through Words and Music: Unique Sources to Béla Bartók's Life and Thought in the Fonds Denijs Dille (B-Br)," Revue Belge de Musicologie 67 (2013), 179-218; and id., "Inter arma moderna non silent musae: Bartók during the Great War," Revue Belge de Musicologie 71 (2017), 209-225.

4. Eugen Szenkár's recollection. See Annette von WANGENHEIM, Béla Bartók "Der Wunderbare Mandarin:” Von der Pantomime zum Tanztheater (Köln: Ulrich Steiner Verlag, 1985), document no. 59. Cf. Elisabeth BAUCHHENSS, Eugen Szenkar (1891-1977): Ein ungarisch-jüdischer Dirigent schreibt deutsche Operngeschichte (Köln etc.: Böhlau, 2016), 70-75. English translation my own. 
versal Edition, Vienna. His most pressing concern was to draft and dispatch a list of minor revisions to his score (practically entirely relating to finetuning the orchestration) based on the preparatory rehearsals in which he participated between 23 and 27 November 1926, ${ }^{5}$ and the première. This correspondence also demonstrates, however, how lucidly Bartók perceived the devastating effect the scandal could have on the possibility of future staged performances of this piece - a work he regarded his most significant for several years.

Nevertheless, the Cologne première scandal likely did not take Bartók by surprise. He was acutely aware of the challenges the scenario and its staging posed and which were the precise factors which elicited the audience's indignation. During preparations for the première, when more than one prominent German opera house, namely Berlin and Munich, were also considered alongside Budapest, the idea of basically revising the libretto - even rewriting it - was repeatedly raised as unavoidable for any stage production. ${ }^{6}$ The libretto was written as a pantomime, a topical literary genre at the turn of the twentieth century in Vienna, by the internationally celebrated playwright Melchior (Menyhért) Lengyel (1880-1974, born Menyhért Lubovics). The pantomime was published in the first 1917 issue of the important literary magazine Nyugat [West]. ${ }^{7}$ Lengyel had previously published a series of writings of a pacifist persuasion in Nyugat, unravelling for the homeland the horrors of the Great War - a fact that should be considered when interpreting the allegedly Grand Guignol character of the original source. ${ }^{8}$ Bartók dated the complete draft of his composition based on Lengyel's pantomime as initiated in October 1918 and completed in May 1919, yet according to a letter to his wife in early September 1918, the composer was already deeply immersed in planning

5. Cf. Béla BARTÓK, Jr., Apám életének krónikája [The chronicle of my father's life] (Budapest: Helikon / Hagyományok Háza, 2/2006 [1/1981]), 247. On the lists of revisions, see László VIKÁRIUS, "A 'Bartók-pizzicato'-ról, egy különös akkordról és A csodálatos mandarin kéziratairól” [On the "Bartók pizzicato," a strange chord and the manuscripts of The Miraculous Mandarin], Muzsika 52/8 (August 2009), 8-11; 52/9 (September 2009), 31-35.

6. See, e.g., the letter by Universal Edition to Bartók, 27 May 1924. The correspondence between Bartók and his publisher in Vienna, Universal Edition, is still largely unpublished. Most of the composer's original letters belong to Peter Bartók's collection, now held in the Paul Sacher Foundation in Basel, whereas letters by the publisher survive partially in Peter Bartók's collection and in Hungarian Bartók collections, Gábor Vásárhelyi's private collection of the Hungarian Bartók estate, and the Budapest Bartók Archives, where copies of all known items belonging to this crucial series of some 1,300 documents can be studied. Some of the letters mentioned or quoted here are available in the selection by Adrienne GOMBOCZ and László VIKÁRIUS, Briefwechsel zwischen Bartók und der Universal Edition: Ein Querschnitt (Budapest: Bartók-Archiv Budapest, Musikwissenschaftliches Institut der Ungarischen Akademie der Wissenschaften, 2003) <https://www.gko.uni-leipzig.de/fileadmin/Fakult\%c3\%a4t_GKO/Musikwissenschaft/2.2-Forschung/ Musikerbriefe/5_Vikarius.pdf $>$ (accessed 13 November 2019).

7. Menyhért LENGYEL, "A csodálatos mandarin: pantomime grotesque" [The Miraculous Mandarin: A grotesque pantomime], Nyugat 10/1 (1 January 1917), 87-93, now accessible online: <https://epa.oszk. hu/00000/00022/nyugat.htm> (accessed 13 November 2019).

8. Lengyel published his pacifist articles under the serial title "Egyszerü gondolatok" [Simple thoughts], see, e.g., the source of the motto above, Nyugat 9/1 (1 January 1916), 40. For a clear differentiation from the Grand Guignol, see Vera LAMPERT, "The Miraculous Mandarin: Melchior Lengyel, his Pantomime, and his Connections to Béla Bartók," in Bartók and his World, ed. by Péter LAKI (Princeton, NJ: Princeton University Press, 1995), 155-156. 
the music at the time of correspondence. ${ }^{9}$ The orchestration, as is well established, was repeatedly delayed and finalized only in 1924. Upon completion, Bartók had composed a series of significant new works such as Improvisations for piano op. 20 (1920), two Sonatas for Violin and Piano (1921 and 1922, respectively), both dedicated to Jelly Arányi, a Hungarian violinist living in London, the Dance Suite for orchestra (1923), and the severely delayed orchestration of the Four Orchestral Pieces (composed in 1912, orchestrated in 1921). A decisive change in the composer's private life - divorcing his first wife Márta Ziegler and subsequently marrying a young piano pupil from the Budapest Academy of Music, Ditta Pásztory - also unfolded during this period. The composer worked on the pantomime's orchestration and revision around the time of the birth of his second son, Péter, on 31 July 1924.

When circumstances allowed for dedicating time to planning the première, the composer was not unwilling to make concessions to the libretto. According to a letter to his publisher of 22 June 1925, Bartók only wished to establish certain prerequisites in the event of any alterations:

Concerning the première of the Mandarin, I have no fundamental objections against a "partial alteration" of the plot under two stipulations: (1) that the work does not leave behind a grotesque aftertaste and (2) that the changes do not contradict the music. Note that the work must not be turned into a show ballet; it was conceived as a pantomime. ${ }^{10}$

Bartók's concern that his music might be used for a "show ballet" might be surprising and somewhat idealistic, but his concerns were well founded. A statement which might be considered a true ars poetica was elicited by a proposed reworking of the libretto. On 11 April 1927, after the scandalous Cologne première and a successful production at the Prague Neues Deutsches Theater [New German Theatre] in February 1927 which he could not attend, Bartók declared:

\begin{abstract}
I have received the revised text of the Miraculous Mandarin today. The changes (particularly from the appearance of the third man onwards) are unfortunately at odds with the music. For this music - in contrast to today's objective, mechanical, etc. tendency - will express psychological processes. Consequently, it is impossible to attach to it a text which expresses a mood contrary to the music. Thus, e.g., original text: the Mandarin enters - the Girl is terrified; altered
\end{abstract}

9. See Bartók's letter to his wife, 5 September 1918, Bartók Béla családi levelei [Béla Bartók family letters], ed. by Béla BARTÓK, Jr. (Budapest: Zenemúkiadó, 1981), 282. The early stages of composition are discussed in Judit FRIGYESI, "Who Is the Girl in Bartók's The Miraculous Mandarin? A Case Study of Mimi’s Deleted Scene and its Dramatic Meaning," Studia Musicologica 53/1-3 (2012), 241-274.

10. GOMBOCZ and VIKÁRIUS, Briefwechsel, 64. All English translations from this source are my own unless otherwise indicated. 
text: the third person (Shiva) enters - heavenly ravishment of the Girl. This is impossible. Do we have to then, if no better and more suitable reworking can be obtained, refrain from staged performances for the time being ? $^{11}$

This declaration about the aim of the music recalls Bartók's complaint a decade earlier regarding objections to his opera Bluebeard's Castle. "The greatest hindrance to its stage production is", he stressed sardonically, "that the plot offers only the spiritual conflict of two persons and the music is confined to the depiction of that circumstance in abstract simplicity."12 Furthermore the emphasis in the 1925 letter on the genre designation "pantomime" should strike the reader as important. Bartók referred to the second meaning of the term as defined in the largest single-volume Oxford Dictionary of English: "a dramatic entertainment, originating in Roman mime, in which performers express meaning through gestures accompanied by music." 13 The basic difference between this type of stage performance and ballet based principally on dance is the basis on which Bartók insists in correspondence that the work should not be referred to as a ballet. Simultaneously, his definition is in clear, and probably calculated, contrast to his earlier stage work The Wooden Prince, which belongs to the tradition of the more dramatic and narrative "Handlungsbalett." ${ }^{14}$ As early as 7 March 1925, Bartók felt obliged to advise his publisher:

I see that U. E. advertises the Mandarin as a ballet. I have to mention that this work is not so much a ballet as it is a pantomime, since only two dances are included in it. It would be much better to call it a pantomime. ${ }^{15}$

The long process of evolution and repeated revisions to the Mandarin is closely linked to the choice of genre. The composer had informed Emil Hertzka, director of Universal Edition, about the composition of the pantomime in July 1919,

11. GOMBOCZ and VIKÁRIUS, Briefwechsel, 74.

12. Béla BARTÓK, "About The Wooden Prince (1917)," in id., Essays, ed. by Benjamin SUCHOFF (London: Faber \& Faber, 1976), 406.

13. Note that the first and most common meaning of the word "pantomime" is "Brit. A theatrical entertainment, mainly for children, which involves music, topical jokes, and slapstick comedy and is based on a fairy tale or nursery story, usually produced around Christmas." See "Pantomime," in Oxford Dictionary of English, ed. by Catherine SOANES and Angus STEVENSON (Oxford: Oxford University Press, 2/2005 [1/1998]), 1273-1274. This well-established British usage illuminates why the genre designation for Bartók's work might be occasionally entirely misunderstood. I am grateful to Paul Merrick who, many years ago, first brought to my attention the special British usage of the word.

14. For a detailed interpretation of Bartók's two "ballets" with regard to the main contrasting tendencies in ballet traditions, see Daniel-Frédéric LEBON, Béla Bartóks Handlungsballette in ihrer musikalischen Gattungstradition (Berlin: Verlag Dr. Köster, 2012).

15. 'Ich sehe, dass die U.E. den 'Mandarin' als ein Ballett anzeigt; ich muss bemerken, dass dieses Werk weniger ein Ballett als eine Pantomime ist, da ja darin eigentlich bloss zwei Tänze vorkommen. Es wäre also entschieden praktischer, dasselbe eine Pantomime zu nennen." English translation my own. 
indicating simultaneously his inability to orchestrate the work. ${ }^{16}$ Four years later, in a letter from 28 August 1923, Hertzka enquired about the new stage work in connection with a performance of Duke Bluebeard's Castle in preparation in Berlin. In his answer on 31 August 1923, Bartók intimated:

It is a shame that the Mandarin is still only in sketches as this would be the appropriate work to be performed alongside Bluebeard. The stupid concertizing and other similar chores have taken up so much of my time that so far, I have not even started writing the full score. However, this delay has certain advantages: different kinds of experiences have convinced me to significantly abridge the music of this pantomime, so that it will not be longer than somewhat over 30 minutes instead of 40 , and to shape the music so that it can be performed outside the stage without any changes. ${ }^{17}$

That Bartók considered the possibility of a complete non-staged performance of the Mandarin so early suggests that the "different kinds of experiences" mentioned in his letter might have related to the audience's prospective objections to the plot. He might have sensed that the work, conceived and created during the social and political turmoil in the wake of the Great War, might be less readily acceptable for the newly-established bourgeois cultural world of the 1920s. Interpreted metaphorically or otherwise, the Mandarin centres on and exposes the force of sexual instinct and its social suppression, combined with an acute critique of social marginalization leading to criminality. Whilst working on the composition it may have appeared reasonable to assume that the problem of sexuality combined with a critique of society on the stage would be tolerated. The idea to loosen the work's exclusive dependency on the opera houses' stages - more conservative, as well as more unambiguous, than the concert hall - by means of a significantly abridged version, might also be related to another aspect of the composer's "experiences." Bartók could utilize the opportunity to observe recent developments in music and musical life on his more eminent concert tours, in 1920 in Berlin and, especially, in 1922 in London, Paris, and Frankfurt. In Frankfurt he could even witness audience reactions to his two former stage works, and how their style was received.

Bartók had no opportunity to hear his pantomime with an orchestra, either on stage or in the concert hall, before the rehearsals for the November 1926 première. He had nevertheless performed the work himself - on his own or with a colleague - on the piano on several occasions, as he did with his other works.

16. "Ich habe in der letzten Zeit die Musik zu einer einaktigen Pantomime von M. Lengyel 'der wunderbare Mandarin' in den Skizzen vollendet ... Leider habe ich zur Instrumentation der Pantomime, ferner zu anderen Arbeiten keine Möglichkeit.” [I have completed the draft of a one-act pantomime by M. Lengyel, "The Miraculous Mandarin" ... Unfortunately, I have no opportunity to undertake the orchestration of the pantomime or else any other work." Bartók’s letter to Universal Edition, 11 July 1919. English translation my own.

17. GOMBOCZ and VIKÁRIUS, Briefwechsel, 61. 
He may have performed this piece for the Dohnányis just after the completion of the draft in spring 1919, as suggested by a letter from 14 May 1919 from Márta Ziegler, although Elza Galafrès's memoir only mentions Bartók showing the score to Dohnányi. ${ }^{18}$ According to an entry in Menyhért Lengyel's diary he heard the music in the home of Bartók's former piano professor, István Thomán, on 5 July $1919 .{ }^{19}$ Bartók took the music with him to Berlin in the spring of 1920 . The four-hand version at this stage was actually only provided with German text, lacking the original Hungarian libretto. This possibly suggests that the score was then intended to be shown to interested colleagues during this extended stay abroad. On 6 April in Bratislava (Pozsony), where he visited his mother during his trip home, Bartók wrote to his wife: "I had a lot of running around to do in Berlin in the last days; I performed the Wooden Prince before a larger audience and, with Strasser, the Mandarin before a smaller one." ${ }^{20}$ We happen to know that he alone performed it (incompletely) before an important admirer of his music, British music critic Cecil Gray, when he visited Bartók in Budapest in 1921. He later stated that he had "seldom suffered so much from music." 21 Philip Heseltine's friend and ally in their campaign against Stravinsky, Gray looked with decided suspicion at Bartók's new interest in what Heseltine called "the ballet craze" of the period. ${ }^{22}$

The Miraculous Mandarin, however, was not intended to be a ballet at all but rather a pantomime. There are only two sections in the entire work which are marked as dances - which was also pointed out by the composer in his letter of 7 March 1925, quoted above. The first features in the scene of the second visitor, where the Girl, in accordance with the plot, invites and encourages the shy young man to dance with her. The second dance is included in the scene following the appearance of the third guest, the Mandarin. The latter is the lonely dance of

18. “[A]s Dohnányi explained: 'As Béla creates he is not conscious of the effects.' How right Dohnányi was is proven by the reception given to Bartók's pantomime, 'The Miraculous Mandarin.' Melchior Lengyel ... had sent a libretto to Dohnányi, but the latter was unable to undertake it, first because his two operas were still unfinished, and second, but more important, he thought the theme, on a grand guignol subject, was more suitable to Bartók's style. Bartók accepted the assignment and later showed the score to Dohnányi, who tried to draw his attention to what he thought must be a mistake in the introduction. Lengyel had set the first scene against the background of Paris, Bartók began immediately with exotic music thus precipitating the atmosphere which should begin to make itself manifest only with the appearance of the Mandarin, and should depict his strange character and strange world." See Elza GALAFRÉS [sic], Lives... Loves... Losses (Vancouver: Versatile, 1973), 236-237.

19. Entry in Lengyel's diary before 5 July 1919: "The other day Béla Bartók played on the piano the music of the 'Miraculous Mandarin' ... to us in the flat of a mutual friend, Professor Thomán ... Wonderful music! Incomparable talent!' See Menyhért LENGYEL, Életem könyve [The book of my life], ed. by József VINKÓ (Budapest: Gondolat, 1987), 156, translation from LAMPERT, “The Miraculous Mandarin," 163.

20. Bartók’s letter to his wife, Márta Ziegler, 6 April 1920, BARTÓK, Jr. (ed.), Bartók családi levelei, 306. István Strasser conducted the 1916 Budapest première of Bartók's Two Portraits.

21. Cecil GRAY, Musical Chairs (London: Home \& Van Thal, 1948), 182, quoted in Malcolm GILLIES, Bartók in Britain: A Guided Tour (Oxford: Clarendon Press, 1989), 122-123, also reprinted in Malcolm GILLIES, Bartók Remembered (London: Faber and Faber, 1990), 68.

22. Heseltine's unpublished letter to Colin Taylor, 17 October 1921, quoted in GILLIES, Bartók in Britain, 123.

Studia Musicologica 60, 2019 
the Girl that should arouse the passion of the seemingly intransigent visitor. The hesitant beginning and gradual development culminating in a brief climax portray how deeply both are imbedded in the plot; neither is intended to represent a dance as a type for its own sake, rather both are integral to the stage action. Neither is conventional, for that matter, even though both allude to the waltz. A comparison between scene structures in the The Miraculous Mandarin and Bartók's earlier ballet, The Wooden Prince, conspicuously demonstrates the diverging role of dance, an essential element of ballet, in these two works (Table 1).

That the genre designation is crucial has already been pointed out by Annette von Wangenheim, whose full-length study on the Mandarin emphasises the problem of genre, as indicated in the subtitle of her book: "Von der Pantomime zum Tanztheater." Wangenheim argues that the piece, ironically, found its success on the stage when it became a "dance play," i.e., a "ballet," albeit a decidedly modernist one, despite the composer's objective to limit a significant part of the stage performance to gestures. Insight into Bartók's own view of the genre is buried in one of his few reports on Budapest's musical life, written between 1920 and 1921. In a piece published in February 1921 in the American Musical Courier under the rather overblown title "Schönberg and Stravinsky Enter 'Christian-National' Budapest Without Bloodshed," he devotes a longer passage to the performance of Ernst von (Ernö) Dohnányi's work, Veil of Pierrette (1909), based on Arthur Schnitzler's pantomime.

Table 1 Scene structure of Bartók's two "ballets"

\begin{tabular}{|c|c|c|c|}
\hline \multicolumn{2}{|l|}{ The Wooden Prince } & \multicolumn{2}{|l|}{ The Miraculous Mandarin } \\
\hline [Prelude] & -8 & [Introduction] & -6 \\
\hline The Fairy & $8-$ & The tramps and the Girl & $6-$ \\
\hline Dance I (The Princess) & $11-18$ & 1st decoy game & $13-$ \\
\hline The Prince & $19-$ & The Old Rake & $17-$ \\
\hline Dance II (The Forest) & $23-38$ & Casting out the Old Rake & $21-$ \\
\hline Dance III (The Brook) & $39-50$ & 2nd decoy game & $22-$ \\
\hline $\begin{array}{l}\text { The making of the Puppet } \\
\text { (The Prince's "work song") }\end{array}$ & $53-$ & $\begin{array}{l}\text { The Shy Young Lad } \\
\text { [1st] Dance }\end{array}$ & $\begin{array}{l}25- \\
26-28\end{array}$ \\
\hline $\begin{array}{l}\text { Dance IV (The Princess } \\
\text { with the Wooden Puppet) }\end{array}$ & $88-120$ & $\begin{array}{l}\text { Casting out the Young Lad } \\
\text { 3rd decoy game }\end{array}$ & $\begin{array}{l}29- \\
31-\end{array}$ \\
\hline The Prince's utter despair & $120-$ & The appearance of the Mandarin & $36-$ \\
\hline $\begin{array}{l}\text { Dance V (The Princess } \\
\text { with the Wooden Puppet) }\end{array}$ & $147-154$ & $\begin{array}{l}\text { Tempo di Valse } \\
\text { Chase }\end{array}$ & $\begin{array}{l}56-58 \\
59-\end{array}$ \\
\hline $\begin{array}{l}\text { Dance VI (The Princess } \\
\text { alluring the Prince) }\end{array}$ & $156-166$ & $\begin{array}{l}\text { 1st killing (by suffocating) } \\
\text { 2nd killing (by stabbing) }\end{array}$ & $\begin{array}{l}78- \\
87-\end{array}$ \\
\hline Dance VII (The Forest) & $167-171$ & 3rd killing (by hanging) & $97-$ \\
\hline The Princess in despair & 172 & Chorus [lament] & $101-$ \\
\hline $\begin{array}{l}\text { Embrace of the Prince } \\
\text { and the Princess }\end{array}$ & 183 & $\begin{array}{l}\text { Embrace between the Mandarin } \\
\text { and the Girl }\end{array}$ & $104-$ \\
\hline [Postlude] & $189-194$ & Death of the Mandarin & 111 \\
\hline
\end{tabular}


[Dohnányi's] pantomime, “The Veil of Pierette," based upon Schnitzler's text, was, as has been the case annually since 1918, included in the repertory of the opera house and already has been given twice this season.

The title role of Pierrette was in each case taken by Elsa Dohnanyi-Galafrès (former member of the Vienna Hofburg Theater) as guest. As Dohnanyi - also as a guest - wields the baton himself, the opera house is able to produce fine effects on these occasions at least, not only musically but stage technically too, for the whole production was placed in the hands of the Dohnanyis, whose careful attention to all stage details was a guarantee for general excellence.

This pantomime does not stand for mass effects or startling decorations pandering to cheap tastes, but demands gestures of unhackneyed refinement and noble expressiveness. Thanks to Mme. Dohnanyi-Galafrès' finished art, which she also revealed in the stage management and in the preparation of the other roles, the scenic performance was a perfect one. We were not shown an ordinary pantomime, but a deep and gripping drama without words, in which Dohnanyi's most characteristic music takes the place of the spoken word. ${ }^{23}$

Bartók was obviously deeply moved by the stage production in autumn 1920 (Plates 1 and 2). ${ }^{24}$ In the published English translation of his article, his description of Dohnányi's pantomime emphasizes the "gestures of unhackneyed refinement and noble expressiveness." His original German text, however, even more clearly expresses his appreciation of the "wonderful congruity" or "coincidence" of gestures and actions with the music: "Jede schauspielerische Geste, jeder Schritt fällt mit der Genauigkeit eines mitwirkenden Instrumentes auf den entsprechenden Ton der schildernden Musikphrase." [Each gesture of the actors and actresses, each step coincides with the relevant tone of the expressive musical phrase with the precision of one of the musical instruments. ${ }^{25}$ Furthermore, his characterization of Dohnányi's work in this performance is significant, as "a deep and gripping drama without words" and that in it "Dohnányi's most characteristic music takes the place of the spoken word." This train of thought, written one and a half years after Bartók completed the draft of the Mandarin, seems to suggest the decisive effect he sought in his own setting of Lengyel's pantomime text. As we learn from Márta Ziegler's letter to her mother-in-law in May 1919, Elza Galafrès should have played the role of the Girl in a hoped-for Budapest première. ${ }^{26}$

23. Béla BARTÓK, "Schönberg and Stravinsky Enter 'Christian-National' Budapest without Bloodshed (1921)," published in László SOMFAI, "Vierzehn Bartók-Schriften aus den Jahren 1920/21: Aufsätze über die zeitgenössische Musik und Konzertberichte aus Budapest," in Documenta Bartókiana, ed. by id. (Budapest: Akadémiai Kiadó, 1977), vol. 5, 72.

24. The two pictures reproduced here appear in GALAFRÉS, Lives...Loves...Losses, 179. The date and place of the pictures' production are not mentioned in the book.

25. BARTÓK, "Schönberg and Stravinsky," 69.

26. Elza Galafrès's involvement in "the direction of dance" and "the choreography" was also considered in connection with the rehearsals for the planned 1931 Budapest performance directed by László Márkus. Cf. 
Plates 1-2 Elza Galafrès as Pierrette in The Veil of Pierrette
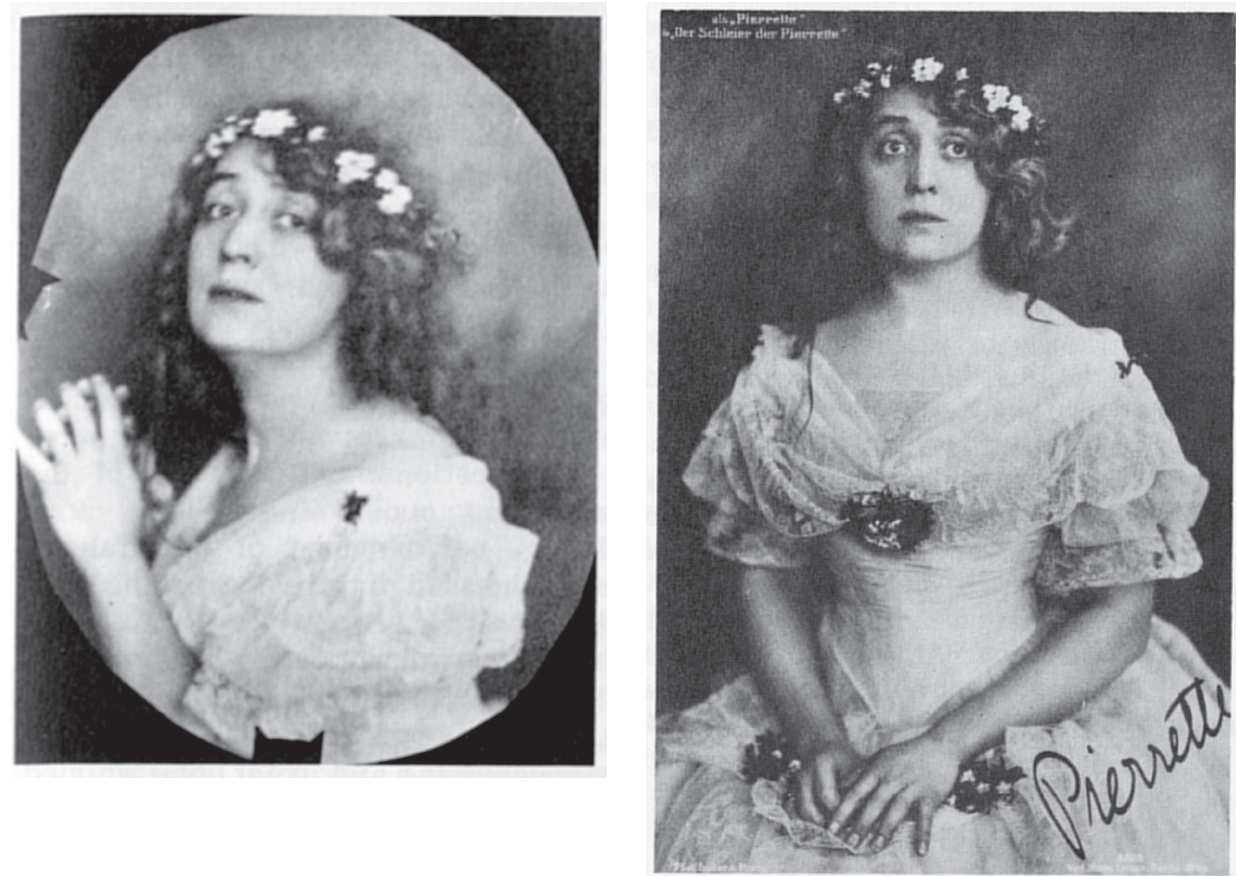

"B. is almost ready with the pantomime and he may soon start orchestrating it. The Galafrèses are already very curious because Elza (who, as you know, is a mimic artist of the opera house) wishes to dance in the role of the Girl." Ziegler adds, as she is the first to confess, "with malice," "they will not like it, that's for sure." 27

Coincidentally, when the Mandarin was performed in Prague in February 1927 (just three months after the unsuccessful world première), it was programmed as a double bill with Dohnányi's The Veil of Pierrette. Understandably, no critic suspected any connection between the music of Mandarin, in which "the grotesque gestures of the orchestra ... embrace the whole gamut of emotions in a novel way," and Dohnányi's “sentimental epigone music," as one critic opined. ${ }^{28}$

Károly KRISTÓF, Beszélgetések Bartók Bélával [Béla Bartók in interview] (Budapest: Zenemükiadó, 1957), 67, newspaper announcement of 9 October 1930.

27. Márta Ziegler's letter to her mother-in-law, 14 May 1919, BARTÓK, Jr. (ed.), Bartók családi levelei, 295. English translation my own.

28. Signed as O. B. and published in the Prager Presse on 22 February 1927, see amongst reviews published in János DEMÉNY, "Bartók Béla pályája delelőjén (1927-1940)" [Béla Bartók at the zenith of his career (1927-1940)], in Zenetudományi tanulmányok Bartók Béla emlékére, ed. by Bence SZABOLCSI and Dénes BARTHA (Budapest: Akadémiai Kiadó, 1962), 203 (=Zenetudományi tanulmányok, vol. 10). 


\section{Music Taking the Place of the Spoken Word}

Pantomime, mimic gestures and actions play an important role even in the generally accessible final (revised) published version of The Miraculous Mandarin. A conspicuous example is found in the scene immediately preceding the second dance mentioned by Bartók. Following the third and final decoy game, the Mandarin, an apparently rich Chinese man, gradually and threateningly emerges to take the place of the previous visitors, the old cavalier and the young man. Here is an English translation of the passage from the original pantomime grotesque by Lengyel: ${ }^{29}$

Mimi again steps to the window timidly, - the exotic music becomes stronger, the creaking of the stairs becomes louder, the Girl keeps watching the door, trembling she retreats to the table - the door opens and the Mandarin stands on the doorstep.

A Chinaman. Thick, yellow face, - slanted, bulging eyes, that do not even quiver, but stare pointedly, like those of a fish. On his head a silk cap, from under it a long black braid falls on his back. Expensive, richly embroidered, full yellow silk coat, a pair of black velvet trousers and a very fine pair of boots.

On his neck a necklace, twisted into many layers. The buttons of his coat glisten, his delicate fingers are full of precious stones.

He stands at the doorstep and looks at the Girl without making a move, his eyes fixed with utmost seriousness.

The Girl is scared of him and retreats. But wherever she goes, to the table, cupboard, or the bed, - the hiding tramps nudge, push her towards the Mandarin. Finally she gets hold of herself and approaches the Mandarin standing in the doorway. She timidly calls him: come closer. The Mandarin makes no move. She calls him again. The Mandarin starts. With an even pace, slowly he comes to the middle of the room. The Girl points at the chair: sit down. The Mandarin sits down. But rigidly and without interruption, - with deathly seriousness and without moving one facial muscle, he continuously watches the Girl.

When working on the music, the composer significantly simplified the text. ${ }^{30}$ This is how it appears in the printed score: ${ }^{31}$

29. In the following I quote from Peter Bartók's translation of Lengyel's text printed before the music in the currently available Universal Edition study score (Philharmonia Ph 550 (C) 2000).

30. All sources suggest that Bartók himself edited the libretto for insertion into the score. He undertook a similar process whilst working on The Wooden Prince. The composer characterized his "simple and extended sentences" that "might not turn out to be worthy of Nyugat" in connection with the edited text of the earlier work. See Bartók's letter to Klára Gombossy, 10 June 1916, quoted in VIKÁRIUS, "Intimations through Words and Music," 201.

31. If not otherwise specified, the quotations from the score are also taken from the Philharmonia study score edition. Regarding the exact placement of the stage directions, the four-hand piano reduction published in 1925 has also been taken into consideration. 
Horrified, she catches sight of a frightfully weird figure in the street, whose steps are already heard on the stairs. - (The three tramps hide.) - The Mandarin enters and remains immobile in the doorway; the Girl flees terrified to the other end of the room. - General consternation. - The tramps make signs furtively from their hiding place that the Girl should start something, lure the Mandarin a little closer, ensnare him. - The Girl overcomes her repugnance and beckons to the Mandarin: "Come closer!" - "Why do you stand so still and stare at me?" - The Mandarin takes two steps - The Girl: "Closer still! Sit down on this chair" - The Mandarin sits down.

Details describing the Mandarin's outward characteristics, including that of his attire, is quite naturally left out of the text printed in the score. The abridged version is largely confined to bodily movements, gestures and the simplest possible indications of psychological reactions. Conspicuously, Bartók occasionally changed the presentation of the text. Whereas Lengyel's pantomime is mainly written in continuous prose, with few allusions to direct speech, Bartók more frequently creates short "utterances" for the characters, and occasionally actual "dialogues" similar to those found in Schnitzler's original pantomime and Dohnányi's setting. These utterances function as verbalized gestures. Furthermore, the strange lack of conventional gestures and expression on the Mandarin's part ("rigidly and without interruption, - with deathly seriousness and without moving one facial muscle, he continuously watches the Girl"), crucial in Lengyel's play, is only implied in the libretto; Bartók conveys this through the Girl's gesture, expressing through her question: "Why do you ... stare at me?"

The music functions to describe and characterize. The libretto printed in the score naturally omits descriptions of sound effects, including even imagined accompanying music such as the "exotic music" mentioned in connection with the approaching Mandarin. Similarly, the libretto does not specify how the Mandarin looks or the impression he imparts; the music should express this unambiguously. The music also translates psychological reactions, and even gestures. For example, we witness a peculiar scene: The three tramps anxiously follow the action on the stage from their hiding place (that is, in the room) and occasionally signal instructions to the Girl. The frightened Girl first attempts to flee but then approaches the Mandarin and shyly attempts to invite him inside. Here, exactly as in his impression of the Budapest performance of The Veil of Pierrette, "Each gesture ... each step" indeed "coincides with the relevant tone of the expressive musical phrase with the precision of one of the musical instruments." Bartók did not consider this section of heightened pantomimic expressivity suitable for performance without stage action, and accordingly omitted this passage from the concert version. Simultaneously, this segment most directly illustrates the musical concept according to which Bartók originally initiated composition in 1918. 
EXAmPLE 1 The appearance of the Mandarin, The Miraculous Mandarin, fig. 36

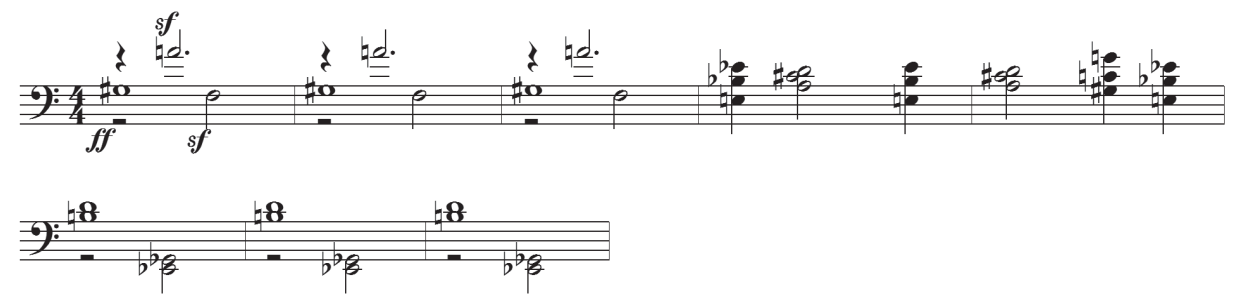

EXAmPLe 2 Excerpt from the "Chase," fig. 71, a) according to the piano reduction; b) the same motif as it appears in the Black Pocket-book
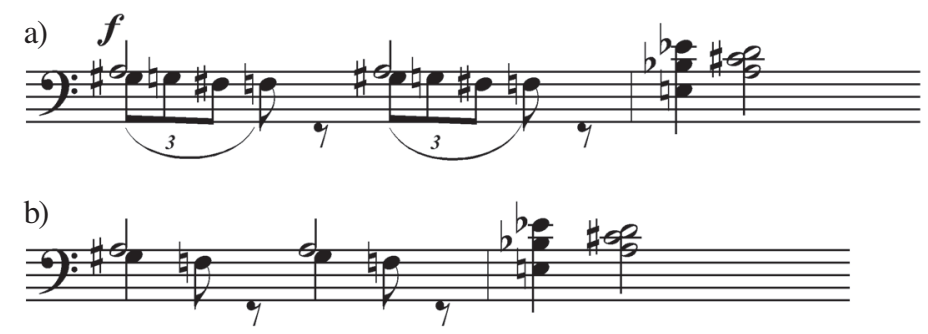

At the scene's outset, a slow falling minor third (A-flat to F) represents the Mandarin's entrance. A strange antithesis of the triumphant fifth door scene in the opera, the scene of the appearance of the Mandarin is as awkwardly disconcerting for the young woman as it is majestic. Although it is tempting to link the main musical symbol, the minor third motif to Bartók's frequent musical gesture, it is important to notice the different spelling in all earlier sources where the same interval appears as an augmented second (G-sharp to F) rather than a minor third (Example 1). The pitch A also becomes part of the musical phrase, thereby involving the major, as well as the minor, third above F. Moreover, what we may perceive as the Mandarin's reminiscence motif appears again with G-sharp following the Mandarin's stumbling, played on the trombone (Examples $2 a$ and b) at fig. 71 (fermata breve) in the Sempre vivace section of the "Chase" scene. If we consider the augmented second as significant, it may appear as the most natural way to characterise the strange visitor. The oriental figure appearing in the Western metropolis is represented by the par excellence symbol of the exotic. It is therefore unsurprising that the same G-sharp to $\mathrm{F}$ augmented second is also prevalent in the final scene of the Mandarin's death.

The complete phrase heard upon the Mandarin's entrance deserves further discussion aside from the crucial initial interval heard several times. It is a theme that uses all twelve tones. ${ }^{32}$ Without being constructed according to the later prin-

32. According to the draft (Source A), Bartók undertook more than one change of harmony before finalizing the phrase in several stages. 
ciples of dodecaphony, it freely but systematically introduces all twelve pitches of the chromatic scale. The closing harmonies subsequently include the previously absent two pitches, B and G-flat. ${ }^{33}$ Formally the theme is also self-contained, expressing perfection in its closure. That both the initial and the final motifs are heard three times emphasizes the phrase's self-containment. There appear, however, musical elements accompanying the theme that do not seem to belong there: the chromatic ornamental notes (similar to a Schleifer) and the trill represent the Girl's frightful reaction. ${ }^{34}$

In the ensuing scene the music reflects each important gesture and "word" especially closely. Each character is represented through what can be described as various musical layers. Pizzicato lower strings (simply staccato in the piano version) portray the muted agitation and nervous movements of the hiding tramps, as they repeatedly nudge towards the Girl yet remain concealed from the Mandarin's view. The hesitant, timid motifs in the woodwind (flute, clarinet, and later oboe) indicate the Girl's gestures and utterances. The focal point of the soundscape is,

EXAMPLE 3 The Miraculous Mandarin, fig. 39

[A leány:]

„Gyere közelebb, -

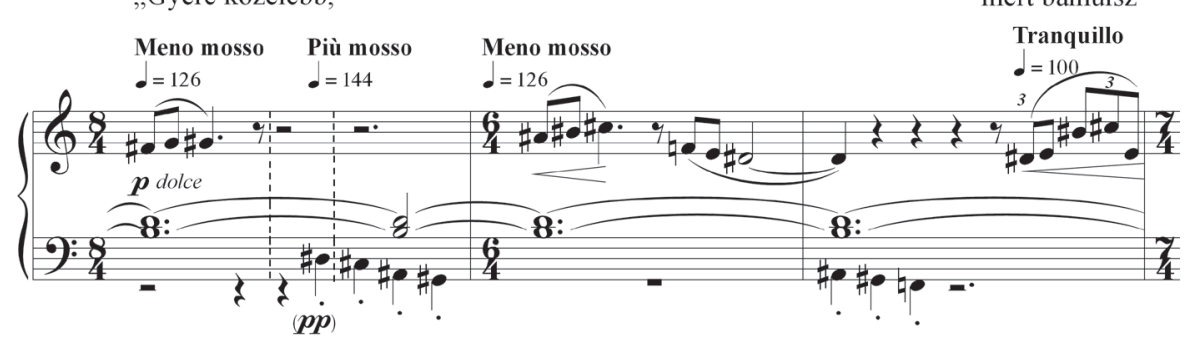

A mandarin

olyan merev mozdulatlansággal rám?" egyet lép, -

és még egyet.

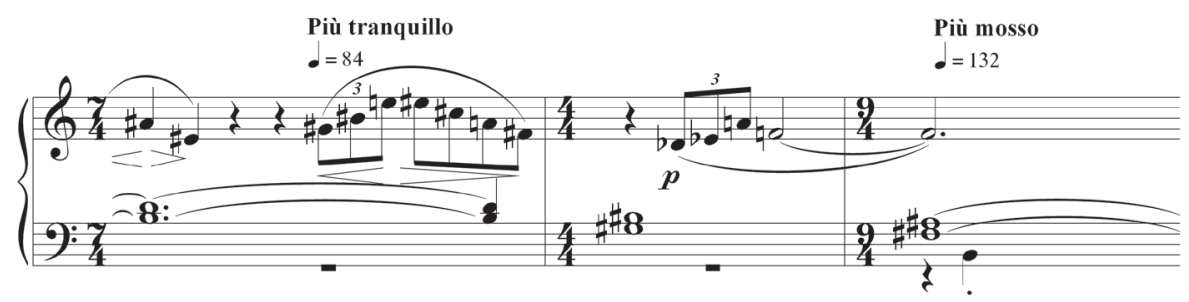

33. The twelve pitches are introduced in the following order (repeated pitches are placed in parentheses): G-sharp, A, F, E/B-flat/E-flat, (A)/C-sharp/D, (A)/C/G, (E/B-flat/E-flat), B/(D), (E-flat)/G-flat. A further tendency characteristic of Bartók is the chromatic, partly symmetrical, extension and narrowing of the harmonic procedure: G-sharp, A, F followed by E/B-flat, then B/E-flat (i.e., F to E to E-flat, and G-sharp to A to B-flat to B), followed by A/C-sharp/D and B-flat/E-flat followed by B/D (i.e., A to B-flat and D to E-flat to D).

34. It is precisely here that the music should have been used to express the "heavenly ravishment of the Girl" in the altered libretto submitted to the publisher and sent to Bartók. 
however, the long-held dyad beginning with a minor third between B and D initially in the horns and subsequently, as if shifting from the outside sound world to an intimate inside sonority, in bassoons. Following the Girl's invitation, the Mandarin finally enters, approaches the chair the Girl indicates, and is finally, stiffly, seated. His rigid movements are each reflected by a descending "step" of the dyad on the scale: B and D; A-flat and C; F-sharp and A-sharp; D-sharp and F-double sharp, and finally C-sharp and E (Example 3 ). ${ }^{35}$ This scene vividly exemplifies Bartók's insistence that his work was a pantomime rather than a ballet. Following this scene, heavily steeped in pantomimic musical-gestural interplay, the second dance mentioned by the composer, an initially "hesitant dance," eventually commences.

Instead of providing further detailed instructions regarding each bar, Bartók presents a succinct summary of what follows at the outset of the following section, and rather allows the score to elucidate. This correlates with the style of the dance scene, which has a distinctly symphonic character in sharp contrast to the previous pantomimic scene. According to the instruction printed after fig. 42, "At last she overcomes her reluctance and begins a hesitant dance." Three bars after fig. 43 appears the summary of what follows in parentheses:

The dance, in accordance with the accompanying music, becomes more determined, culminating in a wildly erotic dance. - Throughout the whole dance the Mandarin's eyes are fixed on the Girl, his stirring passion as yet hardly perceptible in his glance.

No further instructions appear in the score throughout this section, consisting of 100 bars, despite that the stage action does not constitute a continuous and homogeneous dance scene. The dramatic character of this section is marked by frequent tempo changes and the use of fragmented motifs. Finally culminating after fig. 56 "in a wildly erotic dance," the score indicates Tempo di Valse to signpost a new phase in the scene. Prior to this, however, is a single longer and continuous section beginning two bars prior to fig. 50, marked Allegretto (the underlying tempo, despite sporadic slower moments and an a tempo preceding the Tempo di Valse). Stage directions do not accompany this Allegretto section, which appears to unexpectedly interrupt the development of the gradually evolving dance. The character is reminiscent of the previous pantomimic scene, in opposition to the initial dance section. Precisely what happens here is unclear; the sole guide is the original pantomime text. In Lengyel's play, at this moment the Girl is mentioned by name: Mimi. Bartók adopted this name during composition, but later abandoned "Mimi" during the revision stage, opting rather for simply "Girl."

35. The pantomimic nature of the scene is analyzed extensively in LEBON, Bartóks Handlungsballette, 165-168. It is not coincidental that part of the autograph manuscript (Source $\mathbf{B}$ ) of this scene is reproduced on the cover of his book.

Studia Musicologica 60, 2019 
Finally something must be done and Mimi, clumsily, jittering, begins to play. She whisks, dances before the Mandarin - makes herself desirable. She waltzes around the room and, while she passes by the door - suddenly latches it, - and continues her dance. The Mandarin watches her - without moving an eyelash, most seriously. Mimi's dance becomes faster and faster and, when upon a turn she passes in front of the Mandarin, seeing the Mandarin's strange, motionless rigidity - she breaks out in laughter, - more and more intoxicated by the dance, released by the laughter, she falls into the motionless Mandarin's lap.

The stage direction is included only at fig. 59 (Allegro): "The Girl collapses in the Mandarin's lap ...." This corresponds to Lengyel's "she falls into the motionless Mandarin's lap." Bartók adds, however, "he begins to tremble in feverish excitement." The score continues:

But the Girl shudders at his embrace, she tries to tear herself from him, that she finally succeeds in doing. A wild chase begins, the Mandarin tries to catch the persistently fleeing Girl.

Prior to the "Chase," Bartók faithfully follows Lengyel's text (although the original source is markedly more intricate). Lengyel's pantomime portrays the scene thus:

And as the laughing woman lies, slithers, twists in front of him, the Mandarin
undergoes a peculiar transformation. His body succumbs to a silent trembling,
from his soles to the top of his skull. His face gets flushed. The hitherto rigid
eyes flicker and thereafter blink more and more frequently. His chest rises - he
begins to breathe with difficulty, with interruptions. His hands twist here and
there and his fingers find - the Girl's neck - her head... His excitement keeps
increasing. He makes tiny reflex movements, - he twists - shivers, - and sud-
denly begins to tremble throughout his whole body as a result of the hot wave
of his blood transfusing him. The Girl, observing this, - is frightened, - her
laughter ceases, - she jumps up - retreats.
The Mandarin gets up likewise. He extends his arms and starts after the Girl.
The Girl flees, - the Mandarin in her footsteps - his eyes fixed on her - his face
distorted and begging like that of a sick animal.

A chase begins...

Bartók's Hungarian word for the "chase," "hajsza," is different from, and more forceful than, the libretto's "üldözés" (which can also convey "pursuit"). Significantly, Bartók used the same word in Hungarian for his closing piano piece in the Outdoors cycle of 1926, with which he created a paragon of its type. The piano piece clarifies that, for the composer, "Chase" in the pantomime is not just an accidental episode dictated by the libretto but rather an essential element, a crucial type or topos. 
In Bartók's composition, the entire section beginning with the Mandarin's appearance until the "Chase" can be divided into the following subsections (as previously mentioned, stage directions do not feature between figs. 50 and 56):

36 The Mandarin enters: Maestoso

37 General consternation - The Girl: "Come closer," etc.: Non troppo vivo Meno mosso, Più mosso, etc.

40 The Mandarin sits down: Tranquillo - Vivo, Meno vivo, etc.

43 The Girl begins a dance: Lento - ritard. molto - a tempo, etc.

50 -: Allegretto

56 -: Tempo di Valse

59 The Girl falls into the Mandarin's lap: Allegro - Più allegro

62 A wild chase begins: Sempre vivace

The sole section where stage directions are not utilized to aid the narrative is thus the Allegretto section. It is therefore imperative to question what happens here. Motifs from the dance, prevalent so far, suddenly disappear. The trills of the short accelerando from fig. 48 presumably reflect the Girl's (here unmentioned) laughter. In Lengyel's text, references regarding the latter are immediately succeeded by the Girl falling into the Mandarin's lap. It is precisely here that Bartók's music appears to be suddenly, and significantly, more elaborate, as though the culmination of the dance occurs between the Tempo di Valse and her subsequent collapse into the Mandarin's lap. What, then, does the music delineate in the $\mathrm{Al}$ legretto section?

The composer himself drew attention to the significance of this passage when he offered a musical facsimile for the double June 1923 issue of the periodical Nyugat, celebrating the 25th jubilee of the literary career of the founding editor, Ernő Osvát. Bartók selected precisely this Allegretto passage from the four-hand autograph manuscript of The Miraculous Mandarin (Facsimile 1). Two sets of musical facsimiles were included in the special issue: Bartók's score was followed by Kodály's setting of Endre Ady's poem, Sappho's Love Song. The two compositions are in sharp contrast. Kodály's piece is set to an Ady poem, the leading poet of the early period of Nyugat, which itself was closely connected with the cult of Ady. Contrastingly, Bartók's score offers little assistance to the musically interested reader with refined literary tastes. Although the heading informs the reader that the piece is an "Excerpt from the Miraculous Mandarin," that the music is based on a literary work (which was coincidentally published in the same journal), no further explanation to accompany the passage is offered. This might appear typical of the secretive composer, and the selection of this particular passage likely held special, personal, significance. One might even wonder whether it was the enigma of the passage itself that made it particularly suitable for reproduction. The music in the facsimile is extremely difficult to interpret; it contains 
quick passagework in high register in the first pianist's part, and strange, angular motifs, perhaps representing fitful, spasmodic gestures, in the second pianist's part. Tonally free in the extreme, the decidedly dissonant style is demonstrated in the fitful motifs which comprise short, quick figures leaping in large intervals.

In the final orchestration, the lower part is performed by clarinet and bass clarinet. These instruments and the motifs themselves seem to be related to the Girl and her erotic, provocative bodily movements. Analysts of the work have identified that this part of the music might refer to the Girl. ${ }^{36}$ A recent discussion of the passage, furthermore, identifies very convincingly the quick passagework - a high-pitched shimmering sonority achieved in combined piano, harp, and celesta - as representing the Mandarin's gaze. ${ }^{37}$ The music in this scene thus demonstrates the Mandarin looking at the Girl, who is luring, yet simultaneously recoiling from, the title role. Together, these musical elements supplement the missing instructions in the score:

43 The Girl begins a dance: Lento - ritard. molto - a tempo, etc.

48 [The Girl starts to laugh]: Molto sostenuto - molto rallentando - poco a poco accelerando

50 [The Mandarin watches her]: Allegretto

56 [The dance culminates in a wildly erotic dance]: Tempo di Valse

59 The Girl falls into the Mandarin's lap: Allegro - Più allegro

When the composer realized that the pantomime was not suitable for an unchanged complete performance in the concert hall and decided to use an abridged version, he also selected the section discussed here (the scene of the Mandarin). He chose fig. 36 as the beginning and the "Chase" to conclude the concert piece, representing a single scene (or two scenes, as he occasionally mentioned) of the work. This excerpt naturally also included the elusive Allegretto section. ${ }^{38}$ This

36. Two of the most detailed and perceptive descriptions of the music of the scene in the secondary literature refer to the Girl's reaction. Since neither is available in English translation, I am quoting the relevant text in both of them in full in my own rendering. "The leading melody, although it is heard briefly in the clarinet parts (marcato), gives way to a misty, opaque sound. The previously heard piano passages become settled and are foregrounded here. The string tremolo adds a shadow to the soundscape. The hardly perceptible scene seems to refer to the fear and inner struggle of the Girl. It is characteristic that the pair of clarinets creates a momentary twelve-tone cluster. This mood is underlined by the smorzando closing of the scene. This was the last moment of recoil, doubt let itself be felt for the last time.” György KROÓ, Bartók színpadi müvei [Bartók's stage works] (Budapest: Zeneműkiadó, 1962), 219. “This is where these 'repulsions' on the clarinets, if one may refer to them as such, take their extending-narrowing symbolism; their effect is only heightened by the tentacles of the melody stretching intervals of sixths and even sevenths." Ernő LENDVAI, Bartók dramaturgiája [Bartók's dramaturgy] (Budapest: Akkord, 1993), 194.

37. This is not necessarily specifically in the scene in question but repeatedly and quite consistently, Lebon connects the musical representation of the Mandarin's gaze to the appearance of the celesta, whilst also considering the gaze itself as an erotic symbol. See LEBON, Bartóks Handlungsballette, 129-134.

38. Interestingly, however, when playing this first form of the concert piece with György Kósa on the Hungarian Radio in 1926, Bartók probably decided to leave this section out. See the description of his own copy of the published piano reduction (Source $\mathbf{L}$ ) in the Appendix. 
FACSIMILE 1 Allegretto in the four-hand piano reduction as reprinted in Nyugat (June 1923), The Miraculous Mandarin, from fig. 50

\section{Részlet a "Csodálatos Mandarin“„ból BARTÓK BÉLA}

Copyright 1923 by Universal Edition
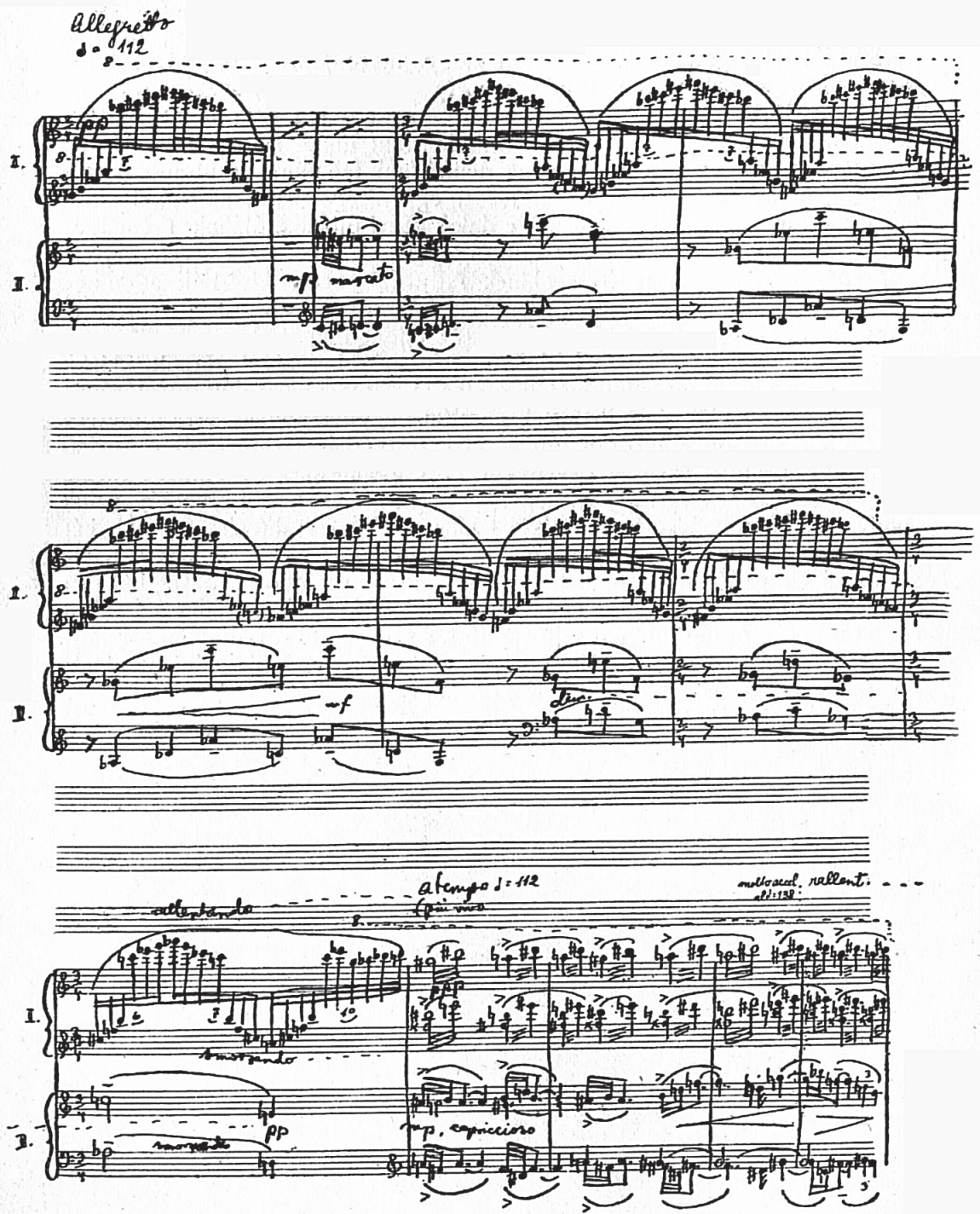


\section{FACSIMILE 1 (continuation)}
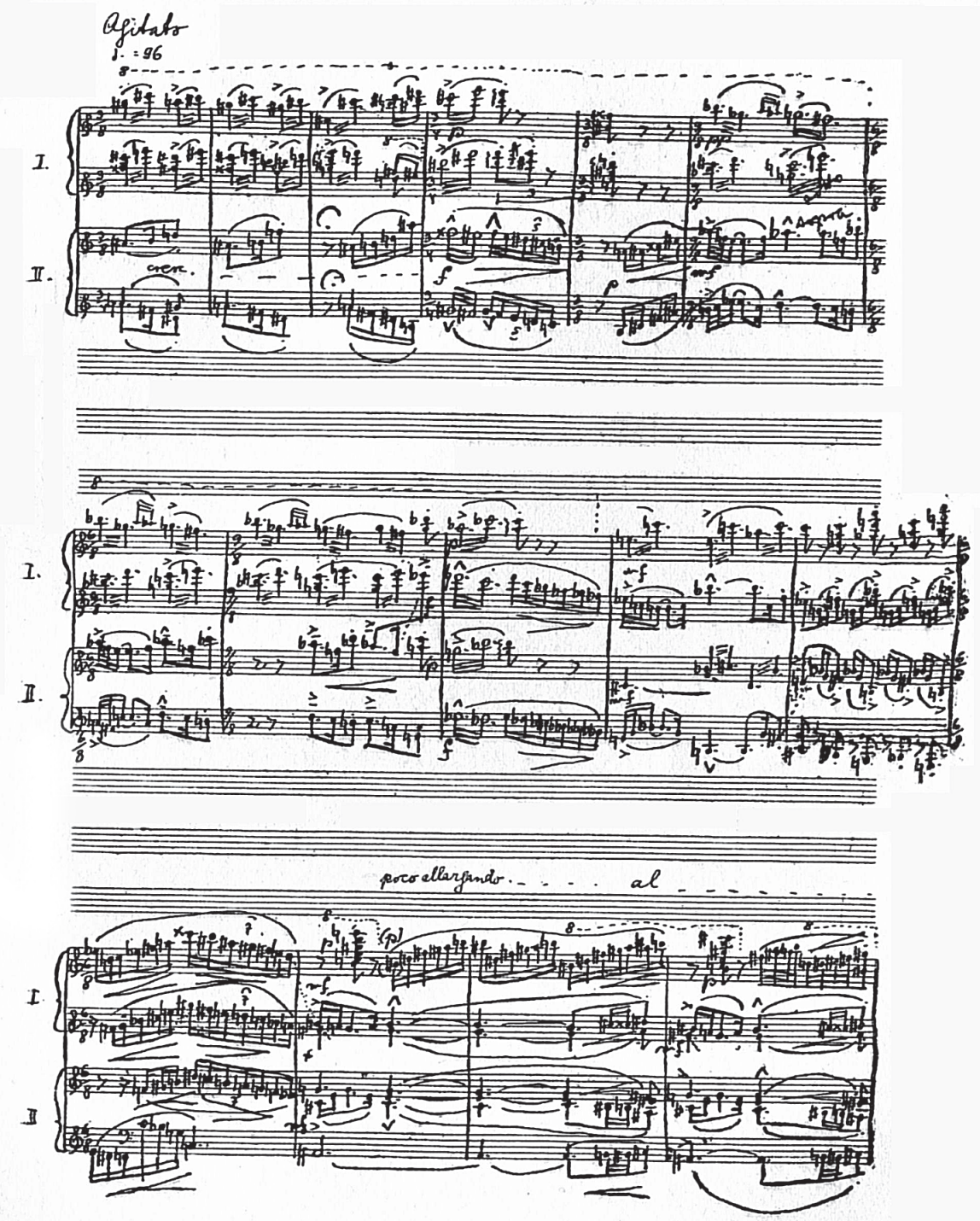
piece, planned to be an independent concert version earlier, subsequently became the second part of the "Scenes from the Miraculous Mandarin," the full score of which was also published in 1927.

The idea to form a "concert version" of the Mandarin became pressing when the prospect of performing the work in the United States was considered. On 22 June 1925 Bartók wrote:

For America, where there is little hope of a staged performance, it would be more advisable to make concert performances of the Mandarin (or more accurately, of one scene thereof). When I sent the final portion of the full score to UE I indicated exactly which section would be suitable for concert performances. I summarize here once more: From [fig.] 36 to bar 7 after [fig.] 74 (inclusively) and then the bars written on the "enclosure" as the ending. This section can be entitled as "A Scene from the Miraculous Mandarin." 39

Thus his initial idea was to use what later became the second part of the concert piece, starting - surprisingly enough - from the moment where the Mandarin enters the room, and closing with the "Chase." Interestingly, no mention was made here of omitting the aforementioned pantomimic passage.

On 6 September 1925, with a performance under Fritz Reiner's baton approaching, Bartók again referred to the short concert version, this time, however, referring to the abridged version as "two scenes" rather than just "one." He clearly referred to the same section beginning with the appearance of the Mandarin at the doorstep.

In the Fall of 1924 when I sent you the full score of the Mandarin, I also wrote to you in a letter that one section of the music is suitable for concert performances and I indicated which section I meant. I also sent you one leaf of manuscript paper (as "enclosure") containing the closing bars. This leaf should be found in the full score you received. Currently, I cannot indicate the beginning and end of the section suitable for concert performances, as I do not have with me the original full score, but I shall be able to do that when I am back in Budapest. Please let me know as soon as possible whether you have found the mentioned enclosed leaf. By the way, this section cannot be entitled "Suite;" it should rather be entitled "Music" or "Two Scenes" from the Miraculous Mandarin. Reiner wants to perform this rather than the Suite from the Wooden Prince. ${ }^{40}$

39. GOMBOCZ and VIKÁRIUS, Briefwechsel, 64.

40. “Im Herbst 1924, als ich Ihnen die Partitur des 'Mandarin' zuschickte, habe ich Ihnen zugleich brieflich mitgeteilt, dass ein Teil der Musik auch zu Konzertaufführungen verwendbar ist und habe angegeben, welchen Teil ich meine. Dazu habe ich eine Seite Partitur als Schlusstakte beigefügt (als 'Beilage'). Diese Seite muss in der Ihnen zugeschickten Partitur sich befinden. - Von hier aus kann ich Ihnen nicht gut Anfang und Ende dieses, zu Konzertaufführungen verwendbaren Teiles angeben, da ich die Originalpartitur nicht hier habe, doch werde ich dies in Budapest nach meiner Rückkehr tun können. Ich bitte sich [= Sie] jedoch mir baldigst mitzuteilen, ob Sie das erwähnte Beilageblatt gefunden haben. - Dieser Teil kann übrigens 
From Budapest he specified the exact details of the section to be used in concert. This time, he excluded the passage between figs. 37 and $44 .{ }^{41}$ Clearly, what he here suggested to omit (and it was indeed left out of the concert version), he considered essential for the stage (and the plot) but unsuitable for concert at that time. $^{42}$

Bartók only decided on the final form of the concert version after the failed success of the Cologne première. On 3 February 1927, he also informed Universal Edition:

Now, after the Cologne première, I see that much larger sections are suitable for concert performance than I had originally envisaged. Thus the new concert version is as follows:

From the beginning to the second bar after fig. 75 (inclusively) with the following two cuts: from bar 3 before fig. 11 to bar 5 after fig. 12. From fig. 37 to bar 2 before fig. 43 (inclusively). After the second bar after fig. 75 follow the specially composed 11 closing bars. ${ }^{43}$

Bartók here described what was subsequently published in the same year as Der Wunderbare Mandarin: Musik aus der gleichnamigen Pantomime, obviously pars pro toto, a substitute or ersatz. ${ }^{44}$ The "Music from The Miraculous Mandarin" finally proved itself. It was premièred on 15 October 1928 in Budapest under Dohnányi's baton and, to the composer's satisfaction, soon became established as a concert item. ${ }^{45}$

keine 'Suite' genannt werden, sondern 'Musik' oder 'Zwei Szenen' aus dem Wund. Mand. Reiner beabsichtigt dieses, und nicht die Suite aus dem Holzg. Prinzen aufzuführen.” English translation my own.

41. "Folgender Teil des 'Mandarins' ist zur Konzertaufführung bestimmt: Von [Nr.] 36 bis [Nr.] 37 (fermata lunga); der folgende Teil, von [Nr.] 37 bis 4. Takt nach [Nr.] 44, wird weggelassen; dann kommt: 6 . Takt vor [Nr.] 45 bis 2. Takt nach [Nr.] 75 einschliesslich; dann folgen die zu diesem Zwecke verfassten Schlusstakte (auf dem 'Beiblatt' oder 'Beilage' in der Ihnen im Herbst 1924 zugeschickten Partitur). Damals, vor zwei Jahren habe ich Ihnen diesbezüglich dasselbe brieflich mitgeteilt, mit dem Unterschied, dass ich damals den Strich zwischen [Nr.] 37 und 4. Takt nach [Nr.] 44 nicht für nötig hielt." [The following section from the Mandarin is intended for concert performance: From fig. 36 to fig. 37 (fermata lunga); the following section from fig. 37 to 4 bars after fig. 44 is left out; then comes: 6 bars before fig. 45 to 2 bars after fig. 75 (inclusively); then follow the specially composed closing bars (on the "enclosure" that I sent you together with the full score in the fall of 1924. Two years ago I also advised you on this in a letter similarly except for the fact that at that time I did not consider necessary the cut between fig. 37 and 4 bars after fig. 44.] English translation my own.

42. Fritz (Frigyes) Reiner conducted this short first form of the concert version on 1 April 1927 with the Cincinnati Symphony Orchestra. See Sarah LUCAS, Fritz Reiner and the Legacy of Béla Bartók's Orchestral Music in the United States (PhD Dissertation, Iowa City, IA: University of Iowa, 2018), 136. An examination of the publisher's original manuscript copy of the concert version (Source $\mathbf{M}$ ) indicates that it must have originally started at fig. 36; see the description in the Appendix.

43. GOMBOCZ and VIKÁRIUS, Briefwechsel, 72.

44. A further short cut, specified in Bartók's letter, from 3 bars before fig. 11 to 6 bars after fig. 12, fourteen bars in all, in which the Girl is presented as she tries to resist the tramps, would break the momentum leading to the first decoy game in a concert performance.

45. See Bartók's 16 October 1928 letter to Universal Edition, GOMBOCZ and VIKÁRIUS, Briefwechsel, 80. 


\section{Manuscript Sources}

An unusually great number of sources document the evolution of Bartók's pantomime. ${ }^{46}$ Although not all primary sources appear to survive, the complexity and number of extant sources makes the task of describing the composition history including more than one stages of revision a real challenge. Independent thematic sketches are entirely missing for the first half of the work, except for the sketches included in the continuous draft itself. It is conceivable that the first half of the music was in fact composed at home through improvisation at the piano, and so the draft (Source A) is in fact the earliest and sole manuscript document for the entire first half of the work. ${ }^{47}$ It is Bartók's Black Pocket-book (Source $\alpha$ ) that has preserved the second half as a mainly continuous, occasionally fragmentary, sketch. ${ }^{48}$ The composer proceeded composition by copying the sections of this part into the draft (Source A). On the basis of the draft, a four-hand version (Source B) was first prepared before his early 1920 trip to Berlin, since it was this score from which he played with conductor István Strasser. It is highly likely that the German stage directions in this score were helpful during this initial and important trip to the West after the First World War. Bartók inadvertently left this four-hand copy of the work with conductor Hermann Scherchen in Berlin, and, when finally turning to the orchestration, he had to request it repeatedly before it was eventually returned..$^{49}$ In the spring of 1921 Bartók signed a contract with the

46. For a basic list of the primary sources, see László SOMFAI, Béla Bartók: Composition, Concepts, and Autograph Sources (Berkeley, CA etc.: University of California Press, 1996), 309. An initial comprehensive attempt to describe the sources in detail was undertaken by Alexander Crouch in his BA dissertation, Alexander CROUCH, The Sources and Evolution of Béla Bartók's The Miraculous Mandarin: A Case-Study (BA Dissertation, Sydney: The University of New South Wales, 1997), 28-49. Unfortunately, however, he did not have access to all the sources and the descriptions are not always entirely reliable.

47. "Béla works on the pantomime by Lengyel and he has completed about half of it. He played it to me last week for the first time and he did so every evening since then." Márta Ziegler's unpublished letter to her mother-in-law, 12 February 1919, quoted in BARTÓK, Jr., Apám életének krónikája, 174. English translation my own. Although it is not specified in this report which half of the work had been completed, it is very likely that the first half is here referred to, therefore it was probably only after early February 1919 that Bartók continued composing on empty pages of his Black Pocket-book. See Béla BARTÓK, Black Pocket-book: Sketches 1907-1922, ed. by László SOMFAI (Budapest: Editio Musica Budapest, 1986). Crouch suggested that sketches for the first part, a continuation of which is found in the Black Pocket-book, might have existed and he included them in his stemma. See CROUCH, The Sources and Evolution, 32.

48. See BARTÓK, Black Pocket-book, ff. 15r-24v. With regard to Bartók's use of his sketchbook generally preserved for use during trips, it should be noted that the composition of The Miraculous Mandarin took place in a particularly politically and socially turbulent period in Hungary - in the wake of the First World War - between the autumn of 1918 and the spring of 1919. In this period the composer was often away from his home in Rákoskeresztúr (then still outside of the capital and only accessible by train). His frequent visits to Budapest, often lodging with friends (especially the Kodálys or occasionally Béla Balázs) might have necessitated his reliance on his sketchbook rather than large-size music sheets for which he required the comfort of his study. The known biographical data are unfortunately not precise or detailed enough to reconstruct daily events regarding this period of Bartók's life.

49. According to Bartók's letter to Emil Hertzka of 7 April 1921: “Aus Berlin habe ich den 4-händigen Auszug des 'Mandarin's nicht erhalten, also bitte ich nun Sie, gelegentlich Ihres bevorstehenden Aufenthaltes in Berlin denselben von Herrn Scherchen irgendwie herauszuzwingen. Gelingt es, so werde ich Ihnen sehr dankbar sein." [I have not received the 4-hand reduction of the "Mandarin" from Berlin, so I am now asking 
Opera House in Budapest for the first performance of the Mandarin, in agreement with his publisher. ${ }^{50}$ According to the contract he first had to submit the piano reduction and the libretto, which were indeed registered by Sándor Herczeg (music librarian between 1905 and 1933 at the Opera House) on 9 May $1921 .{ }^{51}$ Although the libretto has not yet come to light, the piano reduction survives (Source E), a copy produced by Márta Ziegler. This copy, after changes were entered into it, still belonged to the collection of the Opera House and was later donated to the Budapest Bartók Archives. His wife's copy of the two-hand piano reduction was intended for the répétiteur, therefore it was presumably prepared by the time of the 1921 submission. This source is derived from Bartók's autograph of the twohand version (Source C), mentioned in a letter from 29 July 1924 to his publisher in which he promises to send it to them. He was probably able to dispatch it only in November, after finishing the orchestration due to the ensuing revision of the musical text. This manuscript is still preserved, together with material from the archive of Universal Edition, in the Vienna City Library (Wienbibliothek im Rathaus).

The orchestration was completed, together with the first major revision of the work, in 1924. This was undertaken concurrently to the period in which Péter, Bartók's second son and first child with his second wife Ditta Pásztory, was born on $31 \mathrm{July} .{ }^{52}$ For an unknown reason, the preparation of the orchestration is partly reflected in the draft (Source A), and partly in the four-hand version (Source B). This is possibly explained by the hasty work on the full score and the changing availability of sources due to difficulties involved with copying the completed parts. Bartók and his copyists worked occasionally in tandem. Initially, his second wife helped. Later, however, probably in connection with Péter's birth, Márta Ziegler, Bartók's most devoted copyist throughout his early career, came to their aid and took responsibility for the task of copying. Ziegler and Pásztory in turn necessarily worked on copying both the four-hand piano reduction and the full score (Source F). The copy of both the four-hand reduction and the full score (Sources $\mathbf{H}$ and $\mathbf{G}$ ) were intended for, and dispatched in portions to, Universal Edition in the summer and autumn of 1924. A further

you to try and force it out somehow from Scherchen during your upcoming visit to Berlin. Should you succeed, I shall be very grateful.] English translation my own. In his letter of 18 April 1921, director Hertzka promised to meet Scherchen in Berlin and ask for the score to be returned.

50. See Bartók's letter of 22 March 1921. Hertzka acknowledged receipt of a copy of the finalized contract with the Opera House in his letter of 23 May 1921.

51. The voucher is currently held at the Budapest Opera House.

52. The progress on the orchestration can be followed in detail in Bartók's reports included in his correspondence with his publisher. He started work on 5 June 1924, and two days before Péter's birth on 29 July he sent the first part of a copy of both the four-hand piano reduction and the full score (Sources $\mathbf{G}$ and $\mathbf{H}$ ). Freshly completed leaves of the manuscript were sent with three further dispatches on 25 September and 7 and 9 November. 
full score was prepared by a professional copyist for the Budapest Opera House (Source I).

Aside from the sketch in the Black Pocket-book, some of the eight manuscript sources contained already more than one layer of notation due to the revision of the music. The earlier, now obsolete, layers were, however, not always preserved in the sources. Since he revised, at times marginally, in other instances dramatically, several parts of the composition during the lengthy orchestration process, Bartók had to enter changes in earlier sources if he wanted them to reflect the final text. Thus he had to edit the autograph four-hand reduction, and both the autograph two-hand reduction and its copy at the Opera House. The revised text was mainly entered after deleting the earlier version of a passage and inserted as pasted-up pieces of manuscript paper. ${ }^{53}$ In such cases the old text generally survives under or alongside the new text. Occasionally, however, it was necessary for Bartók to discard whole leaves of paper and replace them with new ones containing the revisions. The first version of the piece's conclusion, which survives on four pages of two discarded leaves (Source D), likely formerly belonged to the two-hand reduction, in which they were replaced before the manuscript was sent to Universal Edition. ${ }^{54}$ The early, discarded, final pages of the autograph four-hand reduction were preserved in Bartók's own collection and received scholarly interest quite early. ${ }^{55}$ It corresponds to the piece's earliest (first) ending, also preserved on the leaves separated from the two-hand version and, apart from minor changes, it is also identical with the version in the Black Pocket-book. Only relatively recently has it become evident, however, that important further sections from the early version have been preserved in the crucial manuscript, the four-hand piano reduction. The sections, which have unexpectedly come to light, partly during a restoration of the manuscript, now seem to offer the possibility of a complete reconstruction of the early form of the work. ${ }^{56}$

53. Whereas paste-ups in the manuscripts preserved in the Bartók Archives were opened, those in the autograph two-hand piano reduction in Vienna were not. It was A. Nirschy (Aurél Nirschy-Ott), who first published a long article including many short musical excerpts from the early version, based on the copy of the two-hand piano reduction (Source E) then still held at the Opera House. See A. NIRSCHY, "Varianten zu Bartóks Pantomime Der wunderbare Mandarin," Studia Musicologica 2 (1962), 189-223. Interestingly, the article is dated at the end: $(1951,1959)$. One wonders whether it might have been related to the preparation of the revised edition of the four-hand piano reduction in 1952, and subsequently the first complete edition of the full score in 1955 .

54. These leaves have survived separately amongst papers belonging to Ditta Pásztory's estate and were subsequently added to the collection of the Hungarian Bartók estate. That Bartók carefully preserved these leaves discarded from his manuscript demonstrates that he did not wish to conceal the early version of his work from posterity.

55. John Vinton was the first to present early versions of longer sections from the draft (Source A) and the four-hand reduction (Source B), comparing the 1919 version with the 1924 version in VINTON, "The Case of The Miraculous Mandarin." More recently, four facsimile pages from the final section have been reproduced in Judit Frigyesi's article, FRIGYESI, "Who is the Girl," 246-249.

56. Due to the complete and costly restoration of the draft kindly undertaken at the Sacher Foundation, two seemingly missing pages came to light which were pasted together and whose existence could not have been suspected on the basis of even the best quality colour copy of the manuscript. This section (on original pp. 18 and 19) contains a significant part of the longer version of the young lad's scene, including part of an extended first dance and the end of the scene. 
The evolution of the composition, however, did not end with the publication of the piano four-hand version in 1925. One copy (Source $\mathbf{L}$ ) was used on 8 April 1926, when Bartók and his former pupil György Kósa performed on the Hungarian Radio the section then intended for concert performance: the music beginning with the Mandarin's appearance until the end of the "Chase." 57 Ditta Pásztory and Márta Ziegler's combined copy of the full score (Source G) was probably used by Jenő Szenkár at the Cologne rehearsals and performance, as it contains conductor's markings. The composer must have used his own autograph full score (Source F) during the rehearsals, and this is the source in which he entered some final changes to the orchestration, based on his experiences throughout rehearsals and the single performance. A complete set of orchestral parts and further copies of the two-hand reduction (Sources $\mathbf{J}$ and $\mathbf{K}$ ) were prepared at the Budapest Opera House. ${ }^{58}$ They survive in partly fragmentary form but preserve invaluable documents, such as selected pages from a reduction used and annotated in Italian by Sergio Failoni, who conducted the rehearsals. This was in preparation for an initial performance at the Budapest Opera House in 1931, intended to form part of the celebrations for Bartók's fiftieth birthday, however, this performance was subsequently cancelled. ${ }^{59}$ Censorship would have performed a decisive role in thwarting the realization of this staging, nevertheless, the composer himself might have been frustrated by the compromises at the rehearsals since, according to newspaper reports, he himself cancelled further rehearsals and even reimbursed the advance fee he had received from the Opera House. ${ }^{60}$ It was perhaps in connection with these rehearsals that Bartók once again revised the ending (the third ending), which was entered into the source material at the Opera House as "Új befejezés" (New ending), dated 1931. ${ }^{61}$ This last revision to the final part of the music was prepared in the composer's own copy - a Handexemplar - of the published piano reduction (Source $\mathbf{L}$ ). However, likely due to the lack of prospects for further staged performances, he only sent the final manuscript to his publisher in 1936, when a new production, and even a recording, were temporarily considered. ${ }^{62}$ The full score (Source I) and the orchestral parts (Source K) of the Opera House

57. Markings show that Bartók's own copy of the published four-hand piano reduction (Source L) was used at this radio concert.

58. Cf. Géza KÖRTVÉLYES, “A Csodálatos mandarin az Operaházban” [The Miraculous Mandarin at the Opera House], in id., A modern táncmüvészet útján [On the road of the modern art of dance] (Budapest: Zenemükiadó, 1970), 114-176. See especially the reproduction of régisseur László Márkus's notes in a copy of the score he used during the 1931 rehearsals on pp. 128-134.

59. See Gyula HARANGOZÓ, "Mozaikok az operai balett és pályám történetéből” [Mosaics from the history of ballet at the Opera and from my career], Táncmüvészeti Értesitö 9/1 (1971), 64-79. The fragment from conductor Failoni's copy appears not to have been known or identified yet at the time of Körtvélyes's research.

60. See Bartók's unpublished draft letter of 4 April 1931 in the Bartók Archives (BA-N: 3898) and the copy of the letter in the Budapest Opera House. See, further, the news originally published on 29 March 1931, reprinted in KRISTÓF, Beszélgetések, 79.

61. The final (third) ending in both the copy of the full score used in the Opera House (Source I) and in the orchestral parts are dated 1931 .

62. See Bartók's letter to Universal Edition, 29 January 1936, GOMBOCZ and VIKÁRIUS, Briefwechsel, 141. 
contain a number of further cuts. Many cuts and revoked cuts are also marked in Bartók's own copy of the published piano reduction (Source L). ${ }^{63}$

There is some probability that Bartók undertook a further final, partial or full, revision. There is evidence that Bartók discussed the performance of The Miraculous Mandarin with Gyula Harangozó after the latter's choreography of The Wooden Prince had been successfully staged at the Opera House in $1939 .{ }^{64}$ A contract with the Opera House, signed in September 1940 prior to Bartók's departure to the United States, mentions a reworked version by Harangozó which was eventually performed with his changed scenario after Bartók's death at a commemorative production at the Opera House on 9 December 1945, under the baton of János Ferencsik (who had conducted the Philharmonic Orchestra at the Bartóks' farewell concert in Budapest on 8 October 1940). ${ }^{65}$ Although we unfortunately have no conclusive musical documents of these probable final revisions, various cuts appearing in several sources, including Bartók's Handexemplar (Source L), may have related to discussions with Harangozó. ${ }^{66}$ These cuts generally consist of abridged passages of a few bars and deleted repetitions of motifs. These abridgements were incorporated into the first posthumous publication of the printed full score by Universal Edition in 1955 (see Source O), a decade after the composer's death. ${ }^{67}$ The opinion of Ferencsik might have had some weight in this respect. He emphasized the authenticity of the abridgements:

63. A hand-written copy of the full score of the concert version published in 1927 and the engraver's copy of the posthumously published complete Mandarin are kept at the Wienbibliothek im Rathaus (Sources $\mathbf{M}$ and $\mathbf{O}$ ).

64. According to an as yet unidentified newspaper clipping in the Harangozó collection held at the Dance Archive of the Hungarian Theatre Museum and Institute: "Gyula Harangozó: Béla Bartók submitted his dance play The Miraculous Mandarin to the Opera House several years ago; it has not been performed at the Opera House yet. A few days ago we announced that the Bartók ballet will be performed at the Florence Opera House next season. At the same time the idea was raised that the famous ballet could be performed in Budapest, too. Gyula Harangozó, who, with his wife Ilona Vera, the excellent ballerina of the Opera House, left for summer vacation at Balatonújhely the day before yesterday, reported on the ballet plans next season in the Opera House in the following manner: 'I am first of all occupied with the choreography of The Miraculous Mandarin,' he mentioned; 'I have discussed the complete ballet in detail with Béla Bartók and I am sure that there will be no obstacle to the performance any more'," English translation my own.

65. Cf. contract no. 1587/1940 at the Budapest Opera House, which I accessed thanks to Mr. Gábor Vásárhelyi. Cf. BARTÓK, Jr., Apám életének krónikája, 437, entry for 11 September regarding renewed plans for performance in 1941 with an altered scenario. The première was advertised for 6 February 1941 according to a newspaper clipping in the Harangozó collection of the Hungarian Theatre Museum and Institute. See also the already printed bill reproduced in Bartók a színpadon [Bartók on stage], sel. and ed. by Zita BURDA and Domokos Dániel KIS (Budapest: Osiris, 2006), 127.

66. In the Harangozó collection unfortunately no early copy of The Miraculous Mandarin can be found, only a 1956 copy of the later revised Universal Edition piano reduction. See the list of cuts restored in Peter Bartók's new edition in his "Notes," dated 1999, to the Philharmonia miniature score.

67. According to Peter Bartók's preface to the new edition, the four-hand piano reduction published in 1952 only contained the new ending, while a third (undifferentiated) printing of 1955 also carried out the minor abridgements in the music. Cf. Peter BARTÓK, "Preface," in Béla BARTÓK, Der wunderbare Mandarin, op. 19. Klavierauszug für zwei Klaviere, Neuausgabe 2000, Revision: Peter Bartók (UE 31 432). 
[Bartók] himself did not stick to each note of his dance play [The Wooden

Prince] but in fact demanded certain cuts. Just like in the First Suite or The

Miraculous Mandarin. ${ }^{68}$

Ferencsik conducted a production realized during the composer's lifetime at La Scala in Milan in 1942, where the dancer and choreographer Aurelio (Aurél) Milloss directed the production and danced the title role. Milloss appears not only to have discussed the work with Bartók and the possibility of transforming it into an expressive danced drama, but had also undertaken rehearsals in the composer's presence ${ }^{69}$ An extant letter by Milloss to Bartók, dated 2 April 1936, documents their personal discussion. ${ }^{70}$ Milloss's scores, including a heavily marked-up copy of the original 1925 piano reduction (Source P), are now held in the Fondazione Cini in Venice and might further verify, albeit indirectly, Bartók's possible involvement with the abridged sections..$^{71}$ News of the resounding success of the Milan production on 12 October 1942 might not have reached the composer, who was already in self-imposed American exile. ${ }^{72}$

68. See Így láttuk Bartókot: Ötvennégy visszaemlékezés [Thus we saw Bartók: Fifty-four recollections], ed. by Ferenc BÓNIS (Budapest: Püski, 1995), 193. English translation my own. Ferencsik's own copy of the published piano reduction (bound together with the two other stage works) survives, now held in a private collection. It contains markings of all cuts appearing in the copy of the Opera House and in the Universal Edition score. Although no documentary evidence has come to light, it is possible that Ferencsik was informed directly by Bartók regarding the cuts he entered into his piano reduction. Bartók's marking in the score of Ferencsik's copy of The Wooden Prince is evidence of their discussions of the earlier ballet. Cf. Ferenc BÓNIS, Tizenhárom találkozás Ferencsik Jánossal [Thirteen sessions with János Ferencsik] (Budapest: Zenemükiadó, 1984), 62-63 and the reproduction between pp. 56 and 57.

69. WANGENHEIM, Bartók “Der wunderbare Mandarin," 104, quotes from Milloss's recollection according to which he discussed questions of dance aesthetic with Bartók, who also attended some of his rehearsals. See, further, Alfio AGOSTINI, "Milloss, Milan 1942," Bartók / Bournonville, L'Avant-Scène Ballet / Danse 6 (Paris, 1981), 64-65. Cf. also the interview with Milloss published in BÓNIS (ed.), Így láttuk Bartókot, 209-212.

70. This unpublished letter is found amongst Bartók's papers related to his activities at the League of Nations (BBA, BA-N: 3884). The letter reads as follows: "Igen tisztelt Mesterem! Rendkívül örültem Molnár Imre által küldött üzenetének és Ön által kijelölt vasárnap délután (e hó 5-én), még pedig - ha az így Önnek is megfelel - öt óra tájt, el jövök tiszteletemet tenni. Vagyok mindíg legőszintébb tisztelője Milloss Aurél Cím: Ápr. 24-ig Bpest - Nemzeti Színház Telefon reggel 9-ig 368-88. Állandó cím: Düsseldorf, Schäferstr. 4.” [My Dear Meastro, I was very glad to receive the message sent via Imre Molnár and I shall visit you on the appointed Sunday (on the 5th of this month) at five o'clock if that suits you. Most sincerely yours, Aurél Milloss, Address: until 24 April: Budapest, National Theatre, Telephone: until 9 in the morning 368-88. Permanent address: Düsseldorf, Schäferstr. 4.] English translation my own.

71. I was able to consult Milloss's scores of The Miraculous Mandarin in June 2019 and I am most grateful to Gianmario Borio and Francisco Rocca for their assistance at the music collection of the Cini Foundation, and for generously providing the Bartók Archives with a complete digital copy of this most important source, the 1925 four-hand piano reduction with markings, which also includes a manuscript copy of the new (third) ending inserted in the score. A short description of this invaluable source is also included in the Appendix (Source P). As described there, a particular layer of cuts in this score shows remarkable similarity to a series of cuts in Bartók's own copy (Source L).

72. On the context and significance of the Milan production of the Mandarin, see Nicolò PALAZZETTI, “'Il musicista della libertà:' L'influenza di Béla Bartók nella cultura musicale italiana degli anni Quaranta e Cinquanta del Novecento," Rivista Italiana de Musicologia 50 (2015), 157-159; and id., "The Bartók Myth: Fascism, Modernism and Resistance in Italian Musical Culture," International Review of the Aesthetics and Sociology of Music 47/2 (December 2016), 301-303. 
The most recent edition of the pantomime, edited by Peter Bartók, restores a number of abridged passages in accordance with the 1925 version. The exception is that the 1931 third ending replaces the second, which is printed in an appendix. The cuts were discovered during the preparation of the new edition and they were considered inauthentic. ${ }^{73}$ Although it is likely that they were introduced in connection with a planned performance, considering the gradual evolution of the music of the Mandarin it is plausible that a further condensed version could have satisfied the composer, either definitively or in specific contexts. ${ }^{74}$ In this respect, the cuts cannot necessarily be considered inauthentic, yet their validity remains questionable. The evolution of the composition, including the plethora of ideas discarded throughout the process, can fortunately still be studied in the early layers of the sources.

\section{Gestures of Unhackneyed Refinement and Noble Expressiveness}

The specific passages as well as the layers which became visually compromised by deletions and revisions, or which completely vanished by paste-ups or by being separated from the original manuscripts, form components of the Mandarin's original conception. From these sources, a markedly more pantomimic approach to the genre emerges. An illustrative example of this, thoroughly gestural, musical concept is the second scene.

According to the text printed in the score prior to fig. 18, the Girl asks her first visitor, the Old Rake: "Got any money?" He immediately answers nonchalantly: "Never mind money; what matters is love!" In the final version (Example 4a) the question is accompanied by three chords, interrupted by a single rest at the onset of the Commodo marking. The following bar contains the first half of the answer

73. According to Peter Bartók's hypothesis the smaller cuts, whose music he restored in his new edition, were decided at, and exclusively for, the rehearsals for the planned 1931 Budapest rehearsals. Since, however, these cuts do not appear in the sources specifically linked to these rehearsals, I do not think that a clear link exists. It is more probable that Bartók finalized the last (third) ending in connection with the 1931 rehearsals, although the rehearsals themselves could well have begun with the earlier (actually second) ending. The new ending might even have been one of the reasons why the composer accepted the delay and eventual cancellation of the performance. Bartók finally sent the manuscript of the last (third) ending to his publisher five years later (see his letter of 12 April 1936), which might suggest that further cuts were not yet decided, rather than that cuts relevant only to the 1931 production were considered null and void. If the shorter cuts were only suggested during discussions with Harangozó or Milloss after 12 April 1936, then it is possible that any conclusion must be deduced from a comparison of sources, which might be inconclusive alone or separately, as, for example, Bartók's Handexemplar of the piano reduction, which contains several layers of revisions. But taking into consideration the markings in seemingly secondary sources such as Ferencsik's and Milloss's copies, they might potentially be used as a basis for a reconstruction of a final version. However, even if this last version is restorable, it might only represent an authentic variant form based on discussions with one or more choreographer.

74. Although it is not clear why and how editors at Universal Edition decided to finalize the abridged and revised version of the work for their 1955 edition, it is possible that Ferencsik, who was also music director of the Vienna Staatsoper between 1948 and 1950, may have been involved. The version used at productions directed by Milloss in Milan and Harangozó in Budapest, both conducted by Ferencsik, could also have influenced the publisher's final decision.

Studia Musicologica 60, 2019 
Example 4 The Miraculous Mandarin, fig. 18 in the two-hand piano reduction:

a) in the final version; b) reconstructed according to the early version
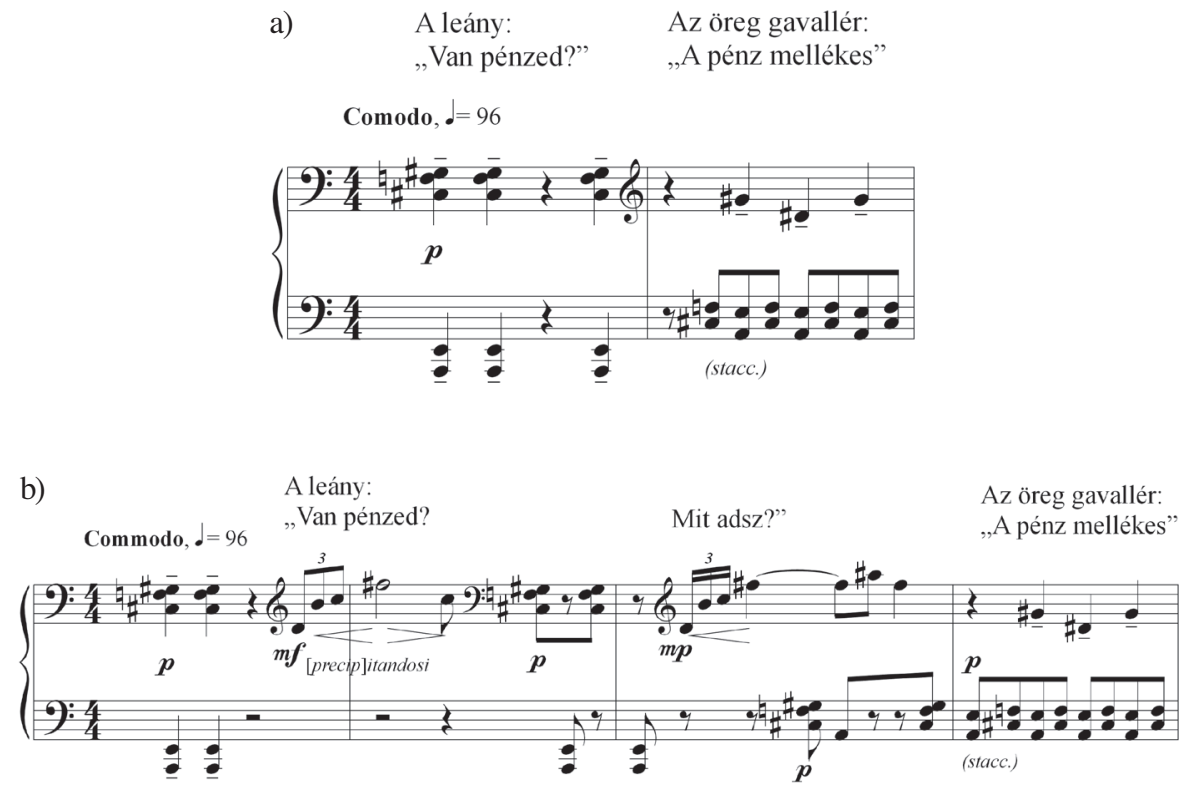

as the slow melody characterizing the Shabby Old Gentleman begins. In the early version of this passage (Example 4b), the Girl asks her hesitant question with psychological sensitivity - shyly, rather than in a harsh or direct manner - attempting twice in different forms: "Got any money? What'll you give me?"75 In the instrumental accompaniment Bartók associated both questions with a musical gesture characteristic of the Girl, similar to the short melodic gestures in woodwind in the pantomimic scene following the Mandarin's arrival. A reliable reconstruction of the original passage is only possible on the basis of a collation of various sources. The reconstruction here presents the text according to the two-hand piano reduction (Sources $\mathbf{C}$ and $\mathbf{E}$ ), however the four-hand draft (Source B), in which certain details are more easily decipherable despite the deletion, was also essential to tran-

75. The early version of this scene was also reproduced in NIRSCHY, "Varianten," 194, his single source being Márta Ziegler's copy of the two-hand piano reduction. However, he could not reconstruct the complete text but rather an amalgamation of two different layers created whilst marking places of erasures. Somewhat similarly, Lebon, when discussing the possibility of analysing the music as concrete musical imitation of speech (musique parlante), he relies on an incomplete form of the early version. Thus he compares the three syllables of the Girl's words "Van pénzed?" [Got any money?] with the three chords and an inserted rest. See LEBON, Bartóks Handlungsballette, 287-289. In the fully reconstructed version it seems clear that Bartók wished to express the question with a motif, probably intended for woodwind rather than imitating the pronunciation of the actual words. (The rest inserted between the chords makes the comparison rather unlikely, anyway.) 
scribing this passage. It is also only the four-hand draft which preserves a different, rather unusual, performance instruction upon the Girl's first question: "leggero con sfacciataggione," that is, in a relaxed and arrogant manner. This probably simulated the Girl's false gestures in this awkward situation. This instruction was replaced by the more neutral precipitandosi in the subsequently prepared two-hand copy.

The revision we witness here appears to be rather similar to those in numerous other passages of the score. Prior to the final scene, the stage direction reads: "the hanging body of the Mandarin begins to glow with a bluish green light, - his eyes are firmly fixed on the Girl." Some of the work's most moving moments are found here, as a chorus sings a lament. Arguably, this is the most revealing section, portraying the depth of the narrative; Bartók's portrayal of the work's transcendental aspects. During this scene, the Girl recognises her power: the figure of the oppressed, exploited Girl becomes the master of the situation, and thereby of the entire narrative.

At last the thought of a solution occurs to the Girl. She makes a sign to the tramps: "Take the Mandarin down!"

The three tramps oblige. The Mandarin falls on the floor and at once pounces on the Girl. She resists no longer... they embrace each other.

According to the final version (Example 5) the tramps sever the braid which holds the Mandarin's body during a general pause. As soon as he has fallen to the ground, the Mandarin jumps up and pounces at the Girl. But when exactly do the tramps approach the hanging Mandarin and how does his body fall to the ground? The memorable descending violin motif that starts on the high E-flat following the long held high $\mathrm{E}$ should only express the embrace itself; all previous actions were given special musical depiction in the early version (Example 6). The passage that now depicts the whole series of stage actions was preceded by the music of the tramps approaching the Mandarin, the release of the body, its falling to the ground (accelerando), and the Mandarin's rushing towards the Girl (appassionato). ${ }^{76}$

The direct musical depiction of stage action was, finally, also prominent in the final section of the closing scene. The composer revised the ending several times (as demonstrated above). To understand Bartók's motivations, it is useful to begin with an examination of the final slow bars (Più lento) of the pantomime. The Mandarin's death is built on two musical elements in the final published version: a chord repetition, which suggests fluttering heartbeats, and a chromatic motif repeatedly reasserting itself as last, waning, signs of life. Both elements are essential

76. Part of this scene and its dramaturgical significance is discussed in FRIGYESI, "Who is the Girl," 266-273. Facsimile of the section from the four-hand piano reduction (Source B) is also included in her article, ibid., 248-249. 
Example 5 The Miraculous Mandarin,

fig. 104: the final version in the two-hand piano reduction

A három csavargó A mandarin a földre zuhan és A leány nem ellenkezik, ezt megteszi egyenesen a leányhoz rohan.

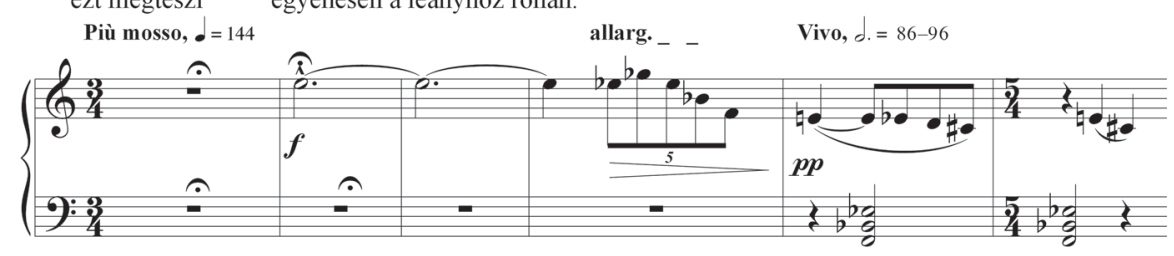

EXAMPLE 6 The Miraculous Mandarin, deleted passage of the early version before fig. 104 (final numbering) in the two-hand piano reduction

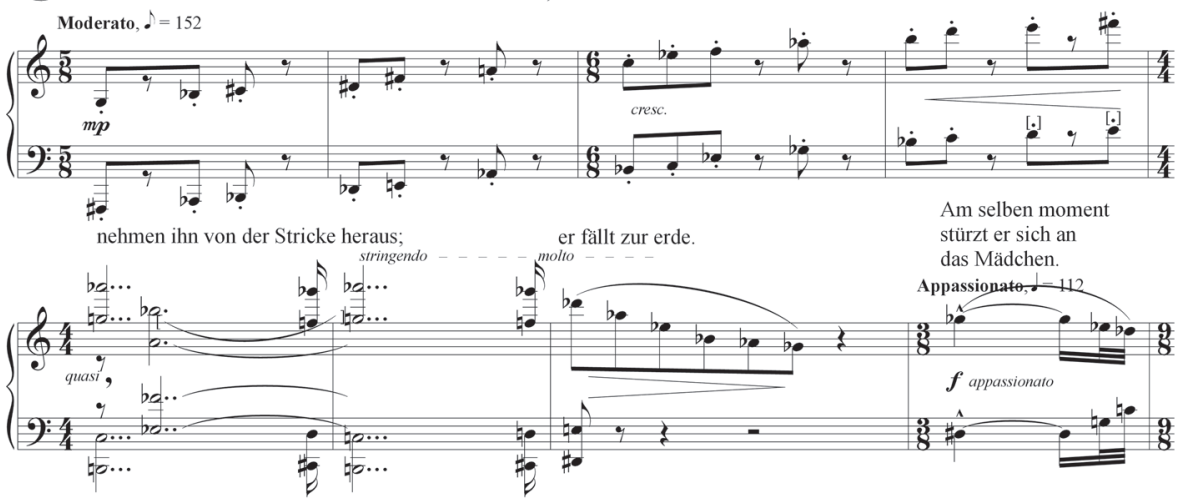

(126) Sie weigert sich diesmal nicht, gibt sich ihm hin

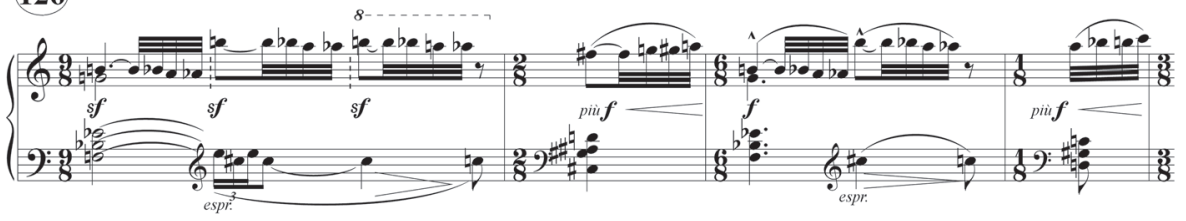

Er küsst sie.

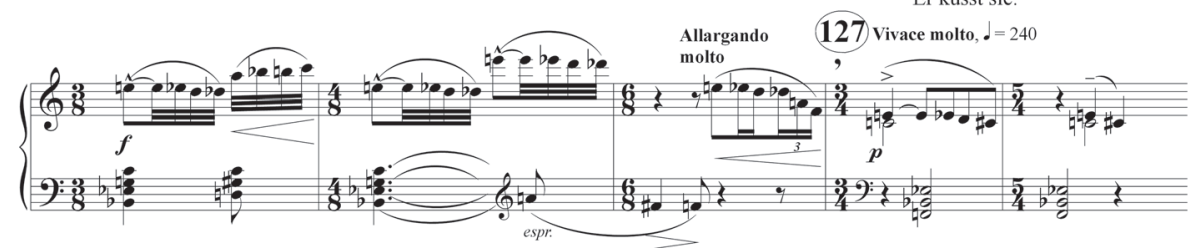


to the musical material from the beginning of the work. The chord repetition first appears at the very beginning of the work, depicting the noise of the metropolis, whereas the chromatic glissando filling the augmented second/minor third interval - a characteristic signal of the Mandarin from his first appearance - is itself related to a shorter three-note glissando associated with the tramps and the Girl. ${ }^{77}$ Here, at the conclusion, the ever softer "dying off" orchestral effect abruptly ends, superseded by a rapid final descending glissando gesture reaching a low register. It concludes with the flutter of the low F-minor chord with an added major sixth (sixte ajoutée). In Lengyel's original pantomime the final passage reads thus:

The Mandarin utters a happy, satiated gurgling sound. Still in contact with the Girl, a trembling runs through his whole body.

Then the wound on his belly and the hole in his forehead slowly begin to bleed. He grows progressively weaker, - his arms, that held the Girl, wilt, his legs collapse. - His eyes still stare - with delight - at the Girl, but they slowly close... His distorted complexion smiles. His desire has been extinguished.

The Girl, with a victorious smile, slowly allows him to settle on the floor, - to the sounds of strange, crackling, exotic music, the Mandarin is dead.

Bartók's published score stipulated only the following: “The Mandarin's longing is now fulfilled, his wounds begin to bleed, he becomes progressively weaker and dies after a short agony."

In the earlier version of the ending found in the four-hand piano reduction of 1925 , which was the only version published during the composer's lifetime, the passage was built on similar elements (although somewhat more elaborately). As the rapid downward glissando is repeated several times followed variously by either the chromatic motif or chord repetitions, it ends now exceptionally and effectively with a single chord. However, it is made more complex by the inclusion of the major third and the augmented fifth (A and C-sharp), alongside the F-minor harmony. Simultaneously, the added major sixth establishes or maintains a relationship to the harmonies already introduced at the first appearance of the Mandarin (see again Examples 1 and 2). Since the final gesture is gradually prepared in this second ending by the earlier use of long descending glissandi, its effect is less dramatic than in the third ending in which it is truly reserved for the very last moment. However, the second ending was already a significantly revised form of an earlier version of the last section found in the drafts. The earliest form fixed in writing is found in the Black Pocket-book. Interestingly, the final gesture, though with the descending glissando omitted, is accompanied by the chord repetition, thereby creating an effect reminiscent of the later third version rather than

77. The dense motivic relationships are examined in György KROÓ, "Monothematik und Dramaturgie in Bartóks Bühnenwerken," Studia Musicologica 5 (1963), 449-467.

Studia Musicologica 60, 2019 
the intermediary second one. Simultaneously, these final chords have a partially different character and meaning in this version. Preceding this final moment, as if in a procession, a series of widely spaced chords unfold symmetrically, reaching $\boldsymbol{f f}$ before receding, suggesting a moment of triumph and pageantry. Prior to this, chords of stacked fifths alongside dotted-rhythm accompaniment suggest a funeral march. The same passage was copied into the final draft (Source A), following slight modifications, and the (later discarded) two-hand piano reduction (Source B). At this stage, even the German text entered into the score was somewhat more elaborate:

und nachdem seine Liebessehnsucht gestillt ist, sinkt er ermattet zur Erde. Seine Stichwunde fängt an zu bluten... er wird immer schwächer... und -- - stirbt.

[After his desire has been satisfied, he sinks to the ground exhausted. His stab wound begins to bleed... he becomes progressively weaker... and ----dies.]

Importantly, it is not the somewhat more elaborate character of the text, but that almost every single word seems to be carefully depicted in the music, which is also found in other passages of the early version of the work. What is already missing from the second ending, the version published in 1925 and subsequently used in rehearsals and performance in 1926 and 1927, are the musical representations of single moments - and single words in the text - such as the exact expression of the Mandarin "getting progressively weaker," his "sinking to the ground" or the "beginning of the bleeding of the wound" (Example 7).

Just as the repeatedly revised final section gradually lost its close connection with distinct moments - and words - of the text, a genuine, symphonic, culmination point began to emerge in the drawn-out closing scene of the pantomime. The final scene, including the cutting down of the Mandarin, his embrace of the Girl and his death, became more condensed, forming part of a single continuous row of closely knit events within one large arc. Meanwhile, a new element, a long and highly expressive, even pathetic, melodic phrase was introduced centrally into the musical structure. Akin to many other passages, the composer also eventually renounced his original pantomimic concept of the music almost throughout this last section, clearly prioritizing the overall effect of the stage work. Some of his carefully calculated and highly expressive musical ideas became obscured in the process, however, the genuine significance of the piece was probably more effectively realised. Here, Bartók finally balanced the dramatic effect of the poignant choral lament by adding the central great melodic outburst of the final section (Examples $8 a$ and $b$ ).

This final melody is completely missing from the early version of the ending. It first appears only in the second ending, albeit still in a rudimentary form. The 
EXAMPLE 7 The Miraculous Mandarin, the earliest ending on discarded leaves of the two-hand piano reduction

und nach dem seine Liebessehnsucht gestillt ist, sinkt er ermattet zur Erde.

(137) $\left(\operatorname{Larg}_{0} \cdot=63\right)$ ritard. _. _ _ al _ _ P Più lento $d=52$

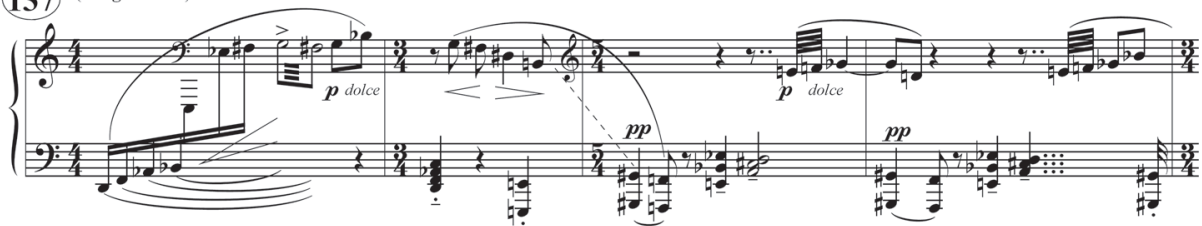

138 allargando
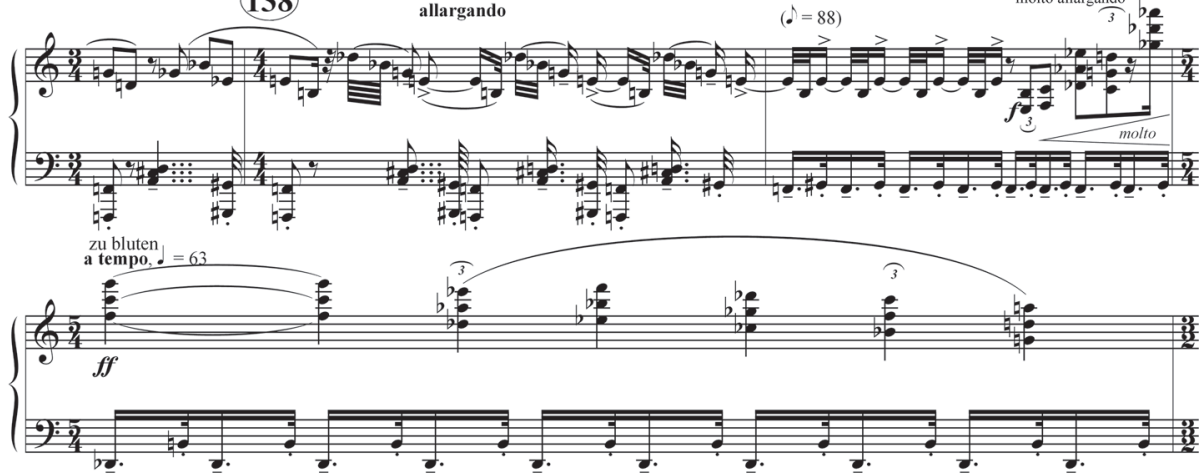

er wird immer schwächer
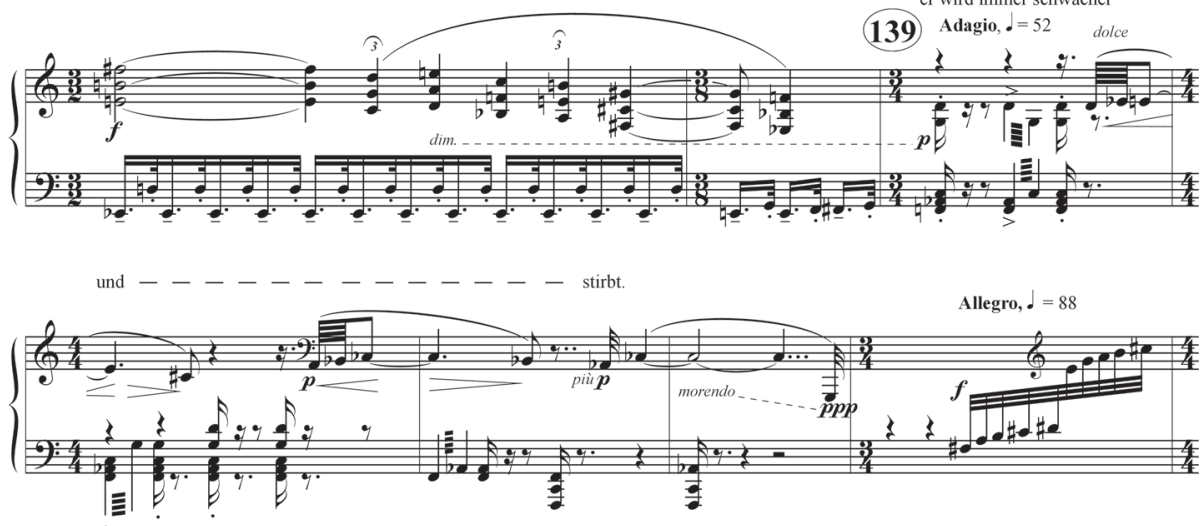

(Vorhang)

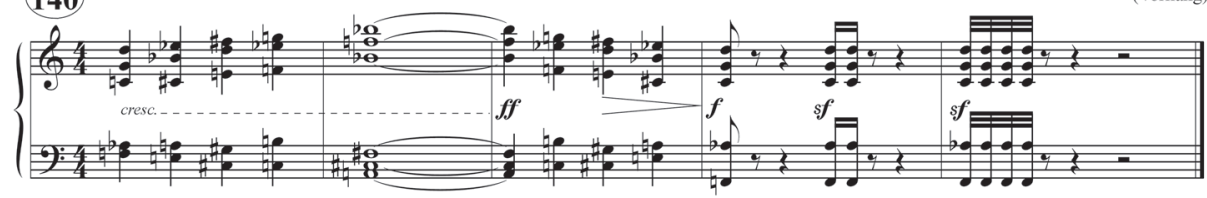


EXAMPLE 8 The Miraculous Mandarin, fig. 108: the great melody of the Mandarin a) in the second ending; b) in the third ending (final version)

a)

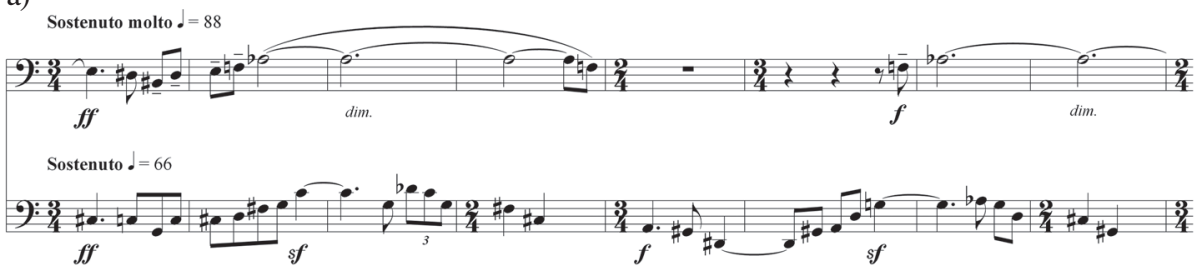

b)

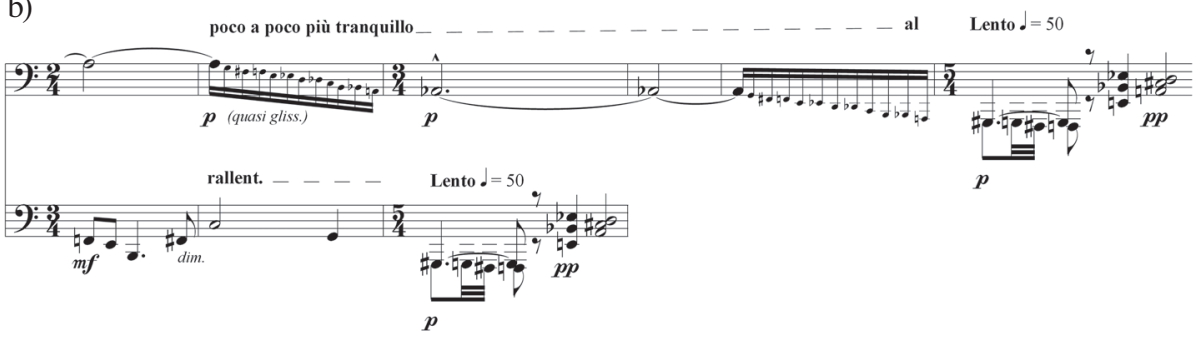

work's full form was finally reached in the further condensed 1931 third ending. ${ }^{78}$ Following this final, truly triumphant, climax exhibiting the Mandarin's seemingly inexhaustible strength, there remained little room for the pantomimic depiction of actions of minor importance. Following this outburst, the music necessarily required less intensity. ${ }^{79}$ This is how Bartók finally managed to shape, in the most concise and most shocking form, the final moments of agony. As mentioned previously, the scene's musical reshaping was sketched in the composer's own copy of the four-hand piano reduction (Source L), which required little further refinement when writing the final text of the last pages.

In a rare statement during an interview in 1929 to one of his most ardent supporters, the Greek-born music critic Michel-Dimitri Calvocoressi, Bartók described the reasons behind the première's scandal. His characterization of the discrepancy between the audience reaction and the actual work seems to make sense of, and shed light on, the reasons behind the repeated revisions, too.

78. There is a surprising analogy between the slow evolution of this passage with that of Bluebeard's hymn-like farewell to Judith, "Szép vagy, szép vagy, százszorszép vagy I Te voltál a legszebb asszony” [Thou art lovely, passing lovely I Thou wert the fairest of my ladies] close to the end of the opera, which, incidentally, also had three successively developed endings, although the respective revisions in the two works are significantly different. See "Commentary" to Béla BARTÓK, Duke Bluebeard's Castle, Opus 11, 1911, Autograph Draft, ed. by László VIKÁRIUS (Budapest: Balassi, 2006), 29-33.

79. This transformation is aptly characterized by Vinton, who concluded that "the one climactic point that Bartók retained described an experience more transcendental than physical." See VINTON, "The Case of The Miraculous Mandarin," 15. 
[O]ne of his [works] has had, of late, a good deal of publicity, the Pantomime Ballet, "The Miraculous Mandarin," whose production at Cologne was accompanied by riotous demonstrations. I was eager to have his own version of what had happened.

"There were," he said, "various reasons for the demonstrations. Before the performance people had read the plot of the 'Mandarin,' and made up their minds that it was objectionable. On the stage the action is carried out at a very brisk pace. From beginning to end the speed is almost breathless, and the effect, accordingly, is quite different from what had been imagined, apparently, by those who had been leisurely speculating upon the possibilities of the subject matter. The 'Mandarin' is very much like an Eastern fairy tale, and contains nothing to which exception can be taken." 80

The Miraculous Mandarin reached its final, most seamless and effective, form in its revised "symphonic" version. The early pantomimic musical style, only preserved intact in certain sections of the piece, was essential to almost the entire original conception. Gestures, words, suggested but left unuttered, and musical phrases are unusually closely intertwined in this work. The musical manuscripts fortunately still preserve Bartók's vigorous and remarkable musical and compositional ideas originating in his period of highest expressionism.

\section{Appendix}

The Miraculous Mandarin, op. 19 (comp. 1918-19, orch. 1924), BB 82 List of Primary Sources ${ }^{81}$

\section{Abbreviations:}

BA-N Shelf-mark at the Budapest Bartók Archives (Bartók Archívum) of the Hungarian Academy of Sciences, Institute for Musicology, Research Centre for the Humanities

BBA Budapest Bartók Archives

$\mathrm{BH}$ Bartók-hagyaték [Hungarian Bartók Estate], GV

f(f). folio(s) 556.

80. Malcolm GILLIES, “A Conversation with Bartók: 1929,” The Musical Times 128/1736 (October 1987),

81. The starting point for generating a list of sources was Somfai’s entry in László SOMFAI, "List of Primary Sources," in id., Béla Bartók: Compositions, Concepts, and Autograph Sources (Berkeley, CA etc.: University of California Press, 1996), 309. Apart from providing a somewhat more detailed characterization of the individual sources enumerated by Somfai, I have also added several new sources, most important amongst them is the relatively recently discovered autograph of the two-hand piano reduction (Source $\mathbf{C}$ ). My own addition is the use of simple sigla (from $\mathbf{A}$ to $\mathbf{P}$ ), which are used here for easy reference as well as the most accessible manner through which to demonstrate the chronological sequence of the sources. In this latter respect my list differs, again, from the list by Somfai who quite logically separated source types, full scores, two-hand and four-hand piano reductions. The aim of the alphabetical sigla in the present list is to show the chronology and the interdependence of the sources. In this respect, an exception is the final and the sole new 
fig. Rehearsal figure

FSFC Full score final copy in source sigla used at the former New York Bartók Archives

GV Gábor Vásárhelyi's private collection including BH

PB Peter Bartók's collection, now deposit at PSF

PN plate number

$\mathrm{p}(\mathrm{p}) \quad$ page(s)

PS Piano sketch in source sigla used at the former New York Bartók Archives

PSF Paul Sacher Foundation (Paul Sacher Stiftung), Basel

TPPFC Transcription for two pianos, final copy, in source sigla used at the former New York Bartók Archives

TPPS Transcription for two pianos, sketch, in source sigla used at the former New York Bartók Archives

UE Universal Edition

$\alpha \quad$ Continuity sketch from the beginning of the "Chase" (fig. 59) to the end (first ending), ${ }^{82}$ Black Pocket-book, ff. 15r-24v (VG, BH: I/206).

A Complete draft in short score format with preparatory notes for orchestration including two versions of the ending (first and second ending), as well as partial sketches for the orchestration (PB 49PS1, deposit at PSF, pages with stamped numbering pp. 1-52, including a title page, blank versos and fragmentary leaves).

B Mostly autograph fair copy in four-hand piano reduction format (with the first and third ending) including drafts of passages and further notes regarding orchestration (PB 49TPPS1, deposit at PSF, title page plus pages numbered pp. 1-60, with pasted-up fragments of music paper; in its original condition two pages were seemingly missing because two leaves were pasted together; the third ending subsequently added; back cover; now with stamped numbering pp. 01-66). Since this source

addition to the last previously published form of the list: Milloss's copy with markings of the four-hand piano reduction (Source $\mathbf{P}$ ) recently examined at the Cini Foundation. My first attempt was published in VIKÁRIUS, “A 'Bartók-pizzicato'-ról," Part 2, 34-35. This was significantly enriched for the article, "A csodálatos mandarin átlényegülései," which forms the basis of my present essay. Note that the useful discussion and stemma of sources in Crouch's thesis have also been taken into consideration, although it is not always reliable as the author could not consult some of the most significant sources (Sources $\mathbf{C}, \mathbf{D}$ and $\mathbf{E}$ ). Moreover, one source, the autograph full score (Source F) is mistakenly identified as the full score copied by Márta Ziegler and Ditta Pásztory (Source G). See his Sources and Evolution, 19 and 41.

82. "First ending" in this list always refers to slightly different versions of the earliest ending, which was revised before the publication of the four-hand piano reduction in 1925. The ending published in Bartók's lifetime is here called (as throughout the essay) the "second ending," while the last, significantly revised, version of the ending labelled in the sources as "new ending 1931" is here called "third ending." 
was originally written with the first ending, it represents an early stage of composition. The second ending in four-hand piano reduction format, originally prepared for this manuscript, is now held with the draft (Source A). The complete manuscript was restored in summer 2012 at PSF and this is how the two seemingly missing pages (original numbering pp. 18-19) finally came to light. An intermediary stage of pp. 27-28 (original numbering) containing the music between 2 bars before fig. 50 to 2 bars before fig. 54 was reproduced in facsimile in Nyugat 16/11-12 (June 1923). The beginning and end of this section is marked in the manuscript. ${ }^{83}$

C Autograph two-hand piano reduction starting only at fig. 6, where the curtain is raised (earlier held at the Historical Archive of UE, now at the Wienbibliothek im Rathaus, Bartók 001; title page with handwriting and numbered pp. 3-35), pasted-up revisions and inserted newly written pages including only the second ending written on subsequently added substitute leaves (pp. 33-35). ${ }^{84}$

D Autograph two-hand piano reduction of the original ending (first ending; music according to the early rehearsal figures: 1 bar before fig. 124 to 5 bars after fig. 140; GV, BH: I/217, 2 leaves, i.e., 4 pages). It probably once belonged to the autograph of the two-hand piano reduction (Source $\mathbf{C}$ ).

E Copy of the two-hand piano reduction prepared for the Budapest Opera House. The beginning (on pp. 1-1a) is Bartók's subsequently added autograph manuscript, since the model of this copy (Source C) did not include the beginning. The continuation is in Márta Ziegler's hand with revised passages in Ditta Pásztory's hand (formerly at the Budapest Opera House, now BBA, BA-N: 2155, title page and pp. 1, 1a, 1b-39). ${ }^{85}$ On the inner title page, in librarian Sándor Herczeg's hand, is: "Bartók Béla I 1921," which suggests that this score was submitted in connection with the production planned for the Budapest Opera House in spring 1921. See also the voucher written and signed by Herczeg: "Csodálatos mandarinból 1 zongora kivonat és 1 szöv[eg]. k[önyv]. érkezett 1921 május hó 9-én Üdvözöl öszinte hived Herczeg" [1 piano reduction and a

83. In some earlier lists, this source was mistakenly considered independent, whose original was lost. A detailed comparison with the autograph four-hand piano reduction clarifies that the facsimile was reproduced from this source; however, the manuscript contains significant later additions as well, and this is why initially it may appear different from the facsimile in Nyugat.

84. This source was first identified on the basis of a facsimile reproduced in an exhibition catalogue Universal Edition, 1901-2001 (Wien: Universal Edition A.G., 2000), 20-21.

85. The two-hand piano reduction was first edited by Peter Bartók: Erstausgabe, 2000, Universal Edition A. G. Wien: UE 31431. 
libretto were submitted on 9 May 1921, With best wishes, Yours sincerely, Herczeg]. The libretto is unfortunately missing.

F Autograph full score with the second ending (PB 49FSFC1, deposit at PSF, title page and pp. 1-127), also including the special ending for the concert version (pp. 129-30) and the full score draft and fair copy of the third ending (PB 49FSFC2, numbered pages with stamped pagination pp. 01-22, the last page is a discarded page originally intended to be a title page). Bartók may have used this manuscript at the rehearsals in Cologne, and he entered his revisions of which he later prepared two lists. Added to the manuscript is furthermore a "Fragezettel" [Questionnaire] with questions from the editor or engraver and Bartók's answers as well as a copy of the changes based on the experience of the Cologne rehearsals entitled "Änderungen im 'Mandarin"” [Changes to the Mandarin]. The list of changes is a copy of an original (now in Wienbibliothek im Rathaus, Bartók 003), itself prepared on the basis of the list which is now kept with the copy of the full score once written for the Opera House (Source I) as a supplement (a).

G Copy of the full score from the Budapest Opera House (Full Score "A"), in Ditta Pásztory's and Márta Ziegler's hands, with Bartók's additions, written with the second ending (BBA, BA-N: 2165, pp. 1-127 and 1 blank page, 1924). The third ending was written on substitute leaves numbered pp. 118-26 intended for this manuscript (now kept in Wienbibliothek im Rathaus, Bartók 024 (D), see Source $\mathbf{O}$ (d)). This full score was given to BBA by the Budapest Opera House where it was held previously (round stamp of the Library of the Hungarian State Opera and a square stamp in which the shelf-number is not entered can be seen on $p$. 1) but it belonged originally to UE as shown on the remaining part of the pasted-up name of the publishing house at the bottom of the front flyleaf and on the stamped name at the bottom of $\mathrm{p}$. 1 . The full score was certainly used as loan material at productions including the première at Cologne in 1926 as it bears conductor's markings (probably also by Eugen Szenkár) throughout the score. On p. 83 (actually subsequently inserted before the original p. 83, which was then changed to p. 83a), Bartók entered instructions for the performance of the first (short) version of the concert piece: "Bei Konzertaufführungen beginnt das Stück bei [Nr.] 36 (Maestoso) und endet (statt S. 83 usw.) mit diesem Schluss" [At concert performances the piece starts at fig. 36 (Maestoso) and closes with this ending (instead of p. 83 etc.)]. On p. 93 (3 bars before fig. 84) the first known instruction to use what is generally called the "Bartók pizzicato" appears to have been entered during the rehearsals in Cologne in 1926: 
"Derart pizz. gespielt, daß die Saite am Griffbrett anschlägt" [A pizzicato should be played where the string rebounds off the fingerboard]. ${ }^{86}$

H Copy of the four-hand piano reduction in the hands of Ditta Pásztory and Márta Ziegler, with Bartók's additions (1924), engraver's copy of the first edition (PN UE 7706, 1925) with the second ending (PB 49TPPFC1, deposit at PSF).

I Copy of the full score made for the Budapest Opera House (Full Score "B") in the hand of copyist Ottó Chomout (1925). ${ }^{87}$ The original notation contains the second ending; the third ending was written on additional leaves and inserted with the inscription "Csodálatos mandarin I partitura, új rész I 1931" [Miraculous Mandarin I full score, new part I 1931] (BBA, BA-N: 2154, title page, flyleaf and music papers with foliation ff. 1-76; original pagination pp. 1-160, plus new ending pp. 1-9). This full score was used at rehearsals for the failed productions in 1931 and 1941 and bears conductor's markings by Sergio Failoni (conductor of the 1931 rehearsals for a planned production); however, it may have been used as early as the 1920s. It is supplemented with two leaves of music paper containing two lists of revisions: (a) an autograph list entitled "Änderungen im 'Mandarin"' [Changes to the Mandarin], based on the experiences at the Cologne rehearsals and performance (pp. 1, 3-4); (b) a further list of revisions in Hungarian (subsequently written on p. 2). Throughout the score, cuts are marked. One layer of these, where blue pencilled brackets and pencilled shading mark off bars to be omitted, seems to correspond to the 1955 UE full score. Further cuts include one marked by red pencilled boxing with pencilled shading (see, e.g., pp. 118-19, where both blue and red markings appear).

J Copies of the two-hand piano reduction made for the Budapest Opera House (currently held at the archive of the Hungarian State Opera House): (1) "Csodálatos mandarin I zongora kivonat I Főrendezői példány I 1926" [Miraculous Mandarin I piano reduction I Régisseur's copy I 1926], 54 pages, with blank leaves inserted between the sheets of music for stage

86. On the appearance of the instruction here and in other sources, see my article, VIKÁRIUS, "A 'Bartók-pizzicato'-ról,' Part 1, 10-11, Part 2, 32-33.

87. Ottó Chomout's name appears in earlier literature mistakenly as "Chamouk." Ottó Chomout was a trombonist in the orchestra of the Budapest Opera House between 1919 and 1945. See A magyar Királyi Operaház évkönyve 50 éves fennállásának alkalmából [Yearbook of the Royal Opera House on the 50th anniversary of its foundation] (Budapest: Magyar Királyi Operaház, [1935]), 10 and 107; and A budapesti Operaház 100 éve [100 years of the Budapest Opera House], ed. by Géza STAUD (Budapest: Zenemükiadó, 1984), 524 (list of orchestral musicians). See, further, the copy signed by Ottó Chomout in the miscellaneous material of the preparatory copy for the 1955 edition of the full score (Source O). 
directions, which were entered in connection with the 1931 rehearsals. It only includes the second ending. (2) "Csodálatos mandarin I zongorakivonat I Színpadi rendező" [Miraculous Mandarin I piano reduction I Stage manager], originally 54 pages but pp. 33-52 are missing and instead part of a different third copy is inserted: (3) pp. 65-76 of a missing copy of the piano reduction (a single ternio), music from 1 bar before fig. 92 to 7 bars after fig. 112. Obviously, this is from the copy used by Sergio Failoni, conductor of the planned 1931 production, as it contains Italian comments probably based on discussions with the composer.

K Almost complete set of orchestral parts prepared for and used by the Budapest Opera House (currently held at the archive of the Hungarian State Opera House), originally 54 separate and numbered volumes (now missing nos. 1, 19 and 38) with title and instrument names, dated 1945 (the date of the final Budapest first performance) on labels pasted on each cover. It was originally copied with the second ending, whereas the third ending was inserted into each part on separate manuscript sheets written in the same hand as the supplement to the full score. All parts include markings of the cuts indicated in the full score as well as individual notes by musicians.

L Bartók's own copy of the UE first edition of the four-hand piano reduction (PN UE 7706, 1925), with a 1-page autograph addition containing the four-hand transcription of the special ending for the concert version (GV, BHadd: 80). Bartók and György Kósa performed an excerpt from this copy on 8 April 1926 on the Hungarian Radio. The last page contains Bartók's autograph sketches for the third ending. Throughout the score there are numerous markings indicating cuts. These were likely entered at different occasions and have different functions. Thus, e.g., the deletion of the whole section between figs. 50 and 54 (the section reproduced in Nyugat and discussed in this article) suggests that it was not part of the excerpt played on the radio. There are three important cuts in the first half of the work: one in the scene of the old rake and one in both the second and the third decoy game. (That in the second was then partially revoked.) Some further short cuts might also be related to the single four-hand performance. Further series of short cuts appear from fig. 79 onwards, which are evidently unrelated to the radio concert and might be related to discussions with choreographers such as Aurelio (Aurél) Milloss or Gyula Harangozó. A previously unknown source, Milloss's own copy of the four-hand piano reduction (Source $\mathbf{P}$ ), shows surprisingly close similarities in one layer of cuts with those in Bartók's copy. 
M Publisher's copy of the concert version with markings probably for engraving but not corresponding to the final edition of the concert version (Wienbibliothek im Rathaus, Bartók 022 (D)). Originally only from fig. 36 on pp. [1]-[4] and 5-60; pp. 1-4 seems to have been replaced when the manuscript became part of the complete concert version and original pp. 5-60 were renumbered as pp. 59-114, whereas the first part of the copy consists of pp. 1-58 (sole numbering). Title page, without pagination, originally for the shorter earlier form of the concert version entitled: "Bartók I Zwei Szenen I aus | 'Der wunderbare Mandarin' | Partitur" [Bartók I two scenes I from I "The Miraculous Mandarin” | full score], which was then changed to "Bartók, I Konzert-Suite I aus I 'Der wunderbare Mandarin' I Partitur” [Bartók, I concert suite I from I "The Miraculous Mandarin" I full score]. Two further changes appear, "Konzert-Suite" was later deleted and replaced by "Szenen" [scenes] in Bartók's hand, and under the title an alien hand entered in parentheses: "(für Konzertaufführungen)" [for concert performances]. The verso of the title page contains the list of instruments in the copyist's hand with additions and corrections in other hands including that of the composer.

N Bartók's own copy of the first edition of the concert version, Der Wunderbare Mandarin: Musik aus der gleichnamigen Pantomime (PN UE 8909, 1927), with autograph corrections and conductor's markings (GV, BHadd: 79). On the verso of the inner title page the instruments are given on a pasted-on printed slip of paper; the "Inhalt der Pantomime 'Der Wunderbare Mandarin"' is printed directly on the page and below it appears Bartók's autograph draft of the scenario in Hungarian for the entire concert version, which was then printed in German translation on an additional slip of paper pasted in copies of the edition later sold, such as the one in BBA (BA-N: 2981, Z. 150).

O Miscellaneous engraver's copy of the first edition of the full score of the complete work in 1955 (PN UE 8909, identical with the PN of the 1927 edition of the concert version; Wienbibliothek im Rathaus, Bartók 024 (D); see also Source G). The source contains four different units. (1) A corrected copy of the original 1927 published full score of the concert version. (2) Three smaller supplements were added to this: (a) a leaf to be inserted between pp. 26 and 27, marked as aa-bb; (b) one bifolio and an added leaf to be inserted between pp. 72 and 73 marked as cc-gg; (c) one bifolio with the inscription "Ballet continuation" marked as hh-kk to be included after the end of the concert version. All three insertions are written on manuscript paper from Zurich (Schutzmarke 
| Musikhaus I Hüni Zürich I No. 330) and added after the 1927 score. Two further additions are found in the copy of the score. (3) An enlarged photo of a manuscript copy of the music from 2 bars before fig. 79 to 6 bars after fig. 103 numbered as pp. 87-116 running continuously, containing editor's markings and corrections entered onto the photocopy. The missing manuscript copy, which was reproduced via photograph, was written by a professional copyist on manuscript paper marked "Beethoven." This copy seems to follow the copy for the Budapest Opera House (Source I) generally leaving out the omitted passages reflected in Source I, although there are differences. Finally, (4) the third ending is written as a special manuscript copy on pp. 118-126 (p. 117 being the title page of this manuscript). The copy of this final section from fig. 104 to the end is signed after the double bar-line: "Chomout Ottó Kngl. ung. opernhaus Bpest." [Ottó Chomout Royal Hungarian Opera House Budapest]. This copy was thus still made by Chomout who worked on the copy of the original full score for the Budapest Opera House (Source I).

P Copy of the first edition of the four-hand piano reduction (1925) from Aurelio (Aurél) Milloss's legacy (Cini Foundation, Venice). On the inner title page in pencil: "Reisz Gy," name of the original possessor, György Reisz known as composer György Ránki, who bequeathed the copy with a dedication to Milloss written in ink: "Milloss Aurélnak őszinte nagyrabecsüléssel és sok szeretettel I Ránky György I 1936." [To Aurél Milloss with highest regard and love I György Ránky I 1936.] The score contains many markings including occasional fingering, numberings likely for purposes of choreography, and more than one layer of deletions. The latter cuts include the deletion (in pencil and red pencil) of the passage between figs. 71 and 76 as indicated by Bartók himself as optional for stage performances. Further short scattered cuts appear from fig. 79 on p. 55 onwards. These seem to have been initially entered in green pencil and then either strengthened or revised in red pencil and occasionally erased, restoring part of what was formerly deleted. A comparison with the deletions in Bartók's own copy of the piano reduction (Source $\mathbf{L}$ ) suggests that these cuts almost exactly match the cuts entered originally in green pencil. Interestingly, a few remarks in Italian by Milloss seem to refer to what he considered Bartók's final decision regarding the cuts. Thus, e.g., on p. 63 over a longer deletion from fig. 91 he wrote in capital letters: "BARTÓK HA LASCIATO POI ANCHE QUESTE 5 BATTUTE IN VITA" [Bartók later restored these 5 bars, too]. The remark might refer either to some information on Bartók's 
"final version" or, more likely, it may refer to a comparison of Universal Edition's later published scores of 1955. (The Cini Foundation also preserves a copy of the 1955 full score, which, again, bears markings by Milloss. As a later source, relevant probably with regard to Milloss's later productions of the Mandarin, it is not considered here.) Amongst the markings, there are very few which resemble Bartók's hand: accel[.] at 5 bars after fig. 17 in blue pencil followed by a short wavy line of extension over the first system on p. 16 and a pencilled calmo 2 bars later and, again, accel[.] at 5 bars before fig. 58, followed by a dashed line of extension up to the end of the line, the last system on p. 41, 1 bar after fig. 58. I find it impossible, however, to identify the hand with certainty. A handwritten copy of the third ending is also held with this source. On the inserted manuscript, obviously written by a Hungarian musician, the title reads "Uj befejezés a mandarinhoz" [New ending to the Mandarin], to the right "zongora I 1931" [piano I 1931]. Immediately above the music in the middle, completely covered by blue ink shading but readable underneath, is the inscription "Failoni mester péld." [Maestro Failoni's Copy]. This suggests that it might have been copied for Sergio Failoni, perhaps in connection with the 1931 rehearsals. This copy might have found its way to Milloss via János Ferencsik in connection with the Scala production of The Miraculous Mandarin in 1942.

Open Access. This is an open-access article distributed under the terms of the Creative Commons Attribution 4.0 International License (https://creativecommons. org/licenses/by/4.0), which permits unrestricted use, distribution, and reproduction in any medium, provided the original author and source are credited, a link to the CC License is provided, and changes - if any - are indicated. 